\title{
The Pannonian Basin System northern margin paleogeography, climate, and depositional environments in the time range during MMCT (Central Paratethys, Novohrad-Nógrád Basin, Slovakia)
}

\author{
Natália Hudáčková, Katarína Holcová, Eva Halásová, Marianna Kováčová, \\ Nela Doláková, Jakub Trubač, Samuel Rybár, Andrej Ruman, \\ Dušan Stárek, Michal Šujan, Michal Jamrich, and Michal Kováč
}

\begin{abstract}
The Miocene global climatic changes together with profound regional tectonic activity significantly influenced the Central Paratethys epicontinental sea. The aim of this study was to reveal relationships between regional and global changes during the beginning Middle Miocene Climatic Transition. The work focused on the northern margin of the Pannonian Basin System, on the key Burdigalian and Langhian sites from the Novohrad-Nógrád and Danube basins (Slovakia). The outcrops and wells reveal variegated facial architecture, environments and processes. The sedimentary record can be subdivided into four main stratigraphic intervals: (i) The late Burdigalian (Karpatian) NN4 Zone. (ii) The earliest Langhian (Karpatian? - earliest Badenian; 14.9 Ma and older), top of NN4/base NN5 Zone. (iii) The lower Langhian (lower Badenian) deposits of NN5 Zone estimated to be $\sim 14.9-14.4$ Ma old. (iv) The late Langhian (lower Badenian) sediments of NN5b-5c Zone with estimated age of $14.4 \mathrm{Ma}$ or younger. Langhian (lower Badenian) rift related volcanism was responsible both for pronounced relief formation and for supply of nutrients and silica into the basin. The Burdigalian/earliest Langhian shelf break slope mudstone (after hiatus) have been replaced by the Langhian inner to outer shelf environment dominated by tidal and wave processes. These were dominated by infaunal foraminifer associations which changed to epiphytic ones. Occasionally the patchreef environment was recorded by miliolide forms. In general, on the southern edge of the Krupina volcanic field the shelf setting passed into deltaic and fluvial deposits. Foraminiferal and calcareous nannoplankton assemblages point more to the nutrient decrease and circulation system change around the Bur/Lan boundary than to warm water condition, followed by cooling during the MMCT. Pollen spectra documents a slight post-Burdigalian cooling and aridification trend.
\end{abstract}

Hudáčková, Natália, Holcová, Katarína, Halásová, Eva, Kováčová, Marianna, Doláková, Nela, Trubač, Jakub, Rybár, Samuel, Ruman, Andrej, Stárek, Dušan, Šujan, Michal, Jamrich, Michal, and Kováč, Michal. 2020. The Pannonian Basin System northern margin paleogeography, climate, and depositional environments in the time range during MMCT (Central Paratethys, Novohrad-Nógrád Basin, Slovakia). Palaeontologia Electronica, 23(3):a50. https://doi.org/10.26879/1067

palaeo-electronica.org/content/2020/3198-south-slovakia-neogene-basins

Copyright: November 2020 Paleontological Society.

This is an open access article distributed under the terms of Attribution-NonCommercial-ShareAlike 4.0 International (CC BY-NC-SA 4.0), which permits users to copy and redistribute the material in any medium or format, provided it is not used for commercial purposes and the original author and source are credited, with indications if any changes are made.

creativecommons.org/licenses/by-nc-sa/4.0/ 
Natália Hudáčková. Department of Geology and Paleontology, Faculty of Natural Sciences, Comenius University in Bratislava, Ilkovičova 6, 84215 Bratislava, Slovakia.natalia.hudackova@uniba.sk Katarína Holcová. Institute of Geology and Palaeontology, Charles University, Albertov 6, 12843 Prague, Czech Republic. holcova@natur.cuni.cz

Eva Halásová. Department of Geology and Paleontology, Faculty of Natural Sciences, Comenius University in Bratislava, Ilkovičova 6, 84215 Bratislava, Slovakia. evahalasova21@gmail.com Marianna Kováčová. Department of Geology and Paleontology, Faculty of Natural Sciences, Comenius University in Bratislava, Ilkovičova 6, 84215 Bratislava, Slovakia. marianna.kovacova@uniba.sk Nela Doláková. Masaryk University, Faculty of Science, Department of Geological Sciences, Kotlářská 2, 61137 Brno, Czech Republic.nela@sci.muni.cz

Jakub Trubač. Institute of Geochemistry, Mineralogy and Mineral Resources, Charles University, Albertov 6, 12843 Prague, Czech Republic. jakub.trubac@geology.cz

Samuel Rybár. Department of Geology and Paleontology, Faculty of Natural Sciences, Comenius University in Bratislava, Ilkovičova 6, 84215 Bratislava, Slovakia. samuelrybar3@gmail.com Andrej Ruman. Department of Geology and Paleontology, Faculty of Natural Sciences, Comenius University in Bratislava, Ilkovičova 6, 84215 Bratislava, Slovakia. winchestersk@yahoo.com Dušan Stárek. Earth Science Institute, Slovak Academy of Sciences, Dúbravská cesta 9, P.O. Box 106, 84005 Bratislava, Slovakia. dusan.starek@savba.sk

Michal Šujan. Department of Geology and Paleontology, Faculty of Natural Sciences, Comenius University in Bratislava, Ilkovičova 6, 84215 Bratislava, Slovakia. miso@equis.sk Michal Jamrich. Department of Geology and Paleontology, Faculty of Natural Sciences, Comenius University in Bratislava, llkovičova 6, 84215 Bratislava, Slovakia. michal.jamrich@uniba.sk Michal Kováč. Department of Geology and Paleontology, Faculty of Natural Sciences, Comenius University in Bratislava, Ilkovičova 6, 84215 Bratislava, Slovakia.michal.kovac@uniba.sk

Keywords: Miocene; Burdigalian; Langhian; foraminifera; sedimentology

Submission: 14 February 2020. Acceptance: 27 October 2020.

\section{INTRODUCTION}

The MMCO (Middle Miocene Climatic Optimum ca. 17-15 Ma) represents the last warm interval in the Earth history (Zachos et al., 2001) and is characterized by warm conditions, comparable to those of the late Oligocene (Pound et al., 2012). Important change associated with an Antarctic ice sheet expansion known as Middle Miocene Climate Transition (15 to $13 \mathrm{Ma}-\mathrm{MMCT}$ ) representing global cooling is expressed in the increase of $\delta^{180} \mathrm{O}$ in foraminiferal records (Holbourn et al., 2005; Shevenell et al., 2008). However, its influence on the specific environment of epicontinental seas, where global trends strongly interfere with local and regional process, is still poorly known. In the Central Paratethys area the climate change was evaluated based on the terrestrial pollen associations by Kováčová et al. (2011) and Kern et al. (2011), which shows a very mild (negligible) trend from Early to Middle Miocene vegetation still of subtropical climate. Mandič et al. (2011) concluded that the optimum climatic conditions triggered the formation of long-lived Gacko Lake (Dinaride Lake
System) between $\sim 15.8$ and $\sim 15.2 \mathrm{Ma}$. The effect of climate change on marine environment in Central Paratethys is evaluated by Piller et al. (1997), Harzhauser et al. (2003), Kováč et al. (2007), Kroh (2007) and confirming global trends. A shift in the global trend was documented in the Central Carpathian Foredeep (Holcová and Demeny, 2012; Holcová et al., 2015, 2018; Scheiner et al., 2018).

The Cenozoic convergence between the European and Adriatic (African) plates resulted in immense changes in the middle European paleogeography (literature summarized by Kováč et al., 2018a). During the Oligocene, these processes resulted in the origin of the semi-closed basin systems consisting of Western, Central and Eastern Paratethys (Popov et al., 2004). Closing and reactivation of seaways, especially during the Miocene ( 23-10 Ma), resulted in environmental changes in the partial depocenters of the Paratethys. The Central Paratethys was one the most influenced (Kováč et al., 2017) and lasted up to the early Serravallian (late Badenian 13.6-12.7 Ma) stage, which represents the last period of marine connection with the Mediterranean Tethys (Báldi, 1980; 
Harzhauser et al., 2002; Kováč et al., 2004, 2018b; Márton, 2006; Harzhauser and Piller, 2007). These processes have affected the terrestrial and marine environment, occasionally interfering with the Mediterranean and the Eastern Paratethys (Sant et al., 2017; Kováč et al., 2017, 2018). During the Burdigalian/Langhian (Karpatian-early Badenian; ca 17.2-15.9-13.6 Ma (Hohenegger et al., 2014; Kováč et al., 2018a, b) resp. 16.3-13.8 Ma (Piller et al., 2007)) the Central Paratethys Sea reached far out into the Central Western Carpathians (Kováč et al., 2017) and the associated sediments can today be found in the Vienna, Danube, Novohrad-Nógrad and in the East Slovakian basins. The depositional environments of the Vienna, Danube and East Slovakian basins (Kováč, 2000; Kováč et al., 2007, 2018b; Rybár et al., 2016) are relatively well known, but on the other hand only a little attention was given to the sediments of the Novohrad-Nógrad Basin, situated at the northern margin of the Pannonian Basin System. The lithofacial character, sediment distribution and paleocurrent patterns of the tidal sandy deposits in this area were originally studied by Čechovič and Seneš (1950), Seneš (1954) and Vass (1977). More details and paleogeographic implication were later added by Vass et al. (1979) and Konečný et al. (1983), and the last lithostratigraphic evaluation was published by Vass (2002).

This study aims to refine knowledge about stratigraphy, depositional systems and about the paleo-climate at the junction of the northern Central Paratethys Sea with the Central Western Carpathians during an interval between the MMCO and MMCT (Burdigalian/Langhian) by utilizing: facies analysis, nannofossils and foraminifer biomarkers together with palynomorphs and other micro-, meio- and macrofauna.

\section{GEOLOGICAL SETTINGS}

The lower Badenian (Langhian) strata sensu Vass (2002) of the Novohrad-Nógrad Basin (Ipel' depression) and Krupina plain (southern part of Central Slovak Volcanic Field) is represented by the volcano sedimentary Vinice Formation onlapping discordantly onto the late Burdigalian (Karpatian) Modrý Kameň Formation. This formation includes two members: (1) the Príbelce Member (40-60 m thick) dominated by fine to coarse, tuffaceous, cross-bedded sands with occasional algal bioherms; and (2) the Hrušov Member (up to $10 \mathrm{~m}$ thick) dominated by mudstone with abundant pumice fragments. The Vinice Formation is discordantly overlain by the Opava and Lysec andezite formations.

\section{MATERIAL AND METHODS}

For this study, seven sections from the South Slovakian basin and one from the Danube Basin were chosen to cover the facial diversity of the Burdigalian/Langhian interval. Additional study was performed in the same area, between Hámor, L'uboriečka and Malý Krtíš vicinity by LKŠ-1, N-80, $\mathrm{N}-65, \mathrm{~N}-91$ hydrological wells (Figures 1, 2). Foraminifera and calcareous nannoplankton study of the well cores were published and stratigraphically ranked according to Zlinská and Šutovská (1991) and Holcová (1996).

Field sedimentological analysis followed standard procedures. The outcrops were leveled by shovels and palette knives. Partial layers were measured, labeled, and photo documentation of key sections was then made by an SLR camera. The uncovered sedimentary structures and textures were documented according to Owen et al. (2011), Rossi et al. (2017) and Patruno et al. (2018) (Appendix 1).

For the purpose of calcareous nannoplankton study standard slides were prepared for a light microscope (normal and crossed nicols, 1000x magnification). About 200-500 specimens of calcareous nannoplankton were determined from each sample and abundances of taxa were enumerated. If the number of individuals was not sufficient the abundances of taxa were expressed semiquantitatively. Determination of calcareous nannoplankton was based on Nannotax database (Young et al., 2020). Dinoflagellate genus Thoracosphaera was included into the calcareous nannoplankton category. Presence of diatoms in nannoplankton slides was also recorded - rare, common and abundant occurrences were distinguished and analyzed (Appendix 2). In total, 79 samples were analyzed, 33 were analyzed quantitatively, 35 did not contain calcareous nannoplankton and 11 could not be analyzed quantitatively due to their scarcity. Abundance of nanoplankton in rock was expressed following the method of Holcová and Zágoršek (2008).

Foraminifers were gained from $200 \mathrm{~g}$ of dried material treated with $\mathrm{H}_{2} \mathrm{O}_{2}(10 \%)$ and subsequently washed using sieves with a mesh size of 1.25 and $0.071 \mathrm{~mm}$. Finally, 250 specimens (benthos and plankton separately) were separated from the samples. If fewer specimens had been present, all foraminifer's tests have been picked from two standardized residuum loads (Appendix 3 ). A com- 


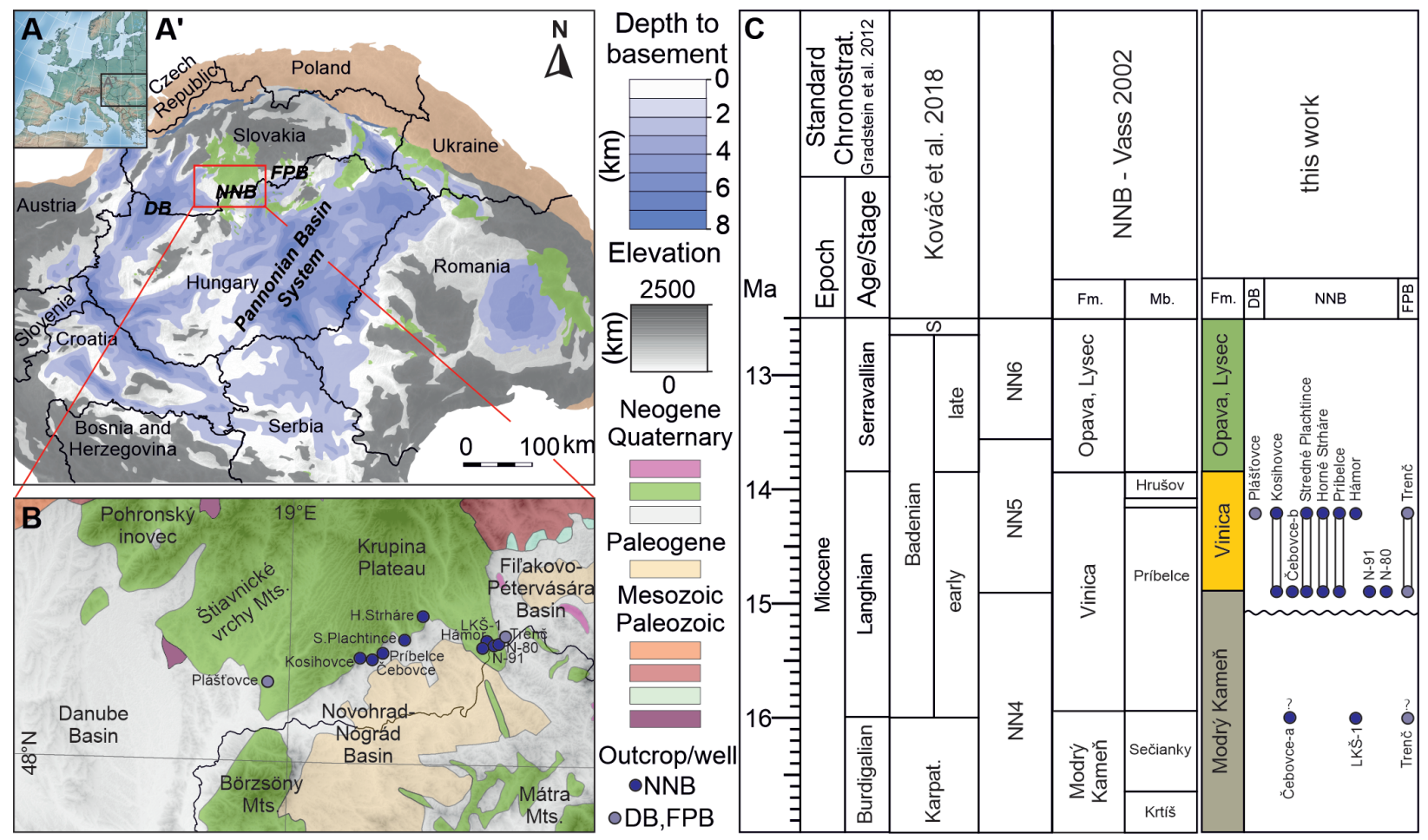

FIGURE 1. Location map. A, A) Position of Novohrad-Nógrád Basin within the Pannonian Basin System. Modified from Rybár et al., 2016. B) Location map of studied sections. C) Lithostratigraphic scheme. Explanatory notes: FPBFil'akovo-Pétervására Basin; DB- Danube Basin; NNB-Novohrad-Nógrád Basin. Modified from Gradstein et al., 2012.

bination of the binocular stereoscopic microscope (Olympus SZ75), the biological polarizing microscope and the scanning electron microscope QUANTA FEG 250 were used during determination and imaging. The taxonomical approach followed Loeblich and Tappan (1992), Cicha et al. (1998) and Holbourn et al. (2013). Due to the poor preservation, some specimens remained in open nomenclature. Paleoenvironmental interpretation of the benthic foraminiferal assemblages is based at diversity and abundance study (Murray, 1973, 2006), and paleoecological parameters were evaluated based on the presence and dominance of taxa (Boltovskoy and Wright, 1976; Murray, 2006). The two-step method developed by Hohenegger (2005) was used for estimation of the paleo water depth of the sedimentary basin. Depth ranges of the foraminifers (Appendix 3C) were adapted mostly from Sgarrella and Montcharmont-Zei (1993), Murray (2006), Spezzaferri and Tamburini (2007) and Sen Gupta et al. (2009).

The stratigraphical correlation was based on stratigraphic ranges of index species from world oceans (Gradstein at al., 2012) and from the Mediterranean (Di Stefano et al., 2008; Abdul Aziz et al., 2008; Hüsing et al., 2010; laccarino et al., 2011).
The local Paratethys biostratigraphy was based on the Cicha et al. (1975), Cicha et al. (1998) and Brzobohatý et al. (2003).

Foraminifera and calcareous nannoplankton assemblages were classified quantitatively and analyzed statistically using the Principal Component Analysis (PCA) of PAST software (Hammer et al., 2001) and nMDS analysis using $R$ package (Venables and Ripley, 2002; R Core Team, 2014; Oksanen et al., 2017).

With regards to the pollen analysis, the samples of dry sediment ( $20 \mathrm{~g}$ per sample) were treated using cold concentrate hydrofluoric and hydrochloric acids to remove mineral matter - carbonates and silicates. The application of heavy liquid $\left(\mathrm{ZnCl}_{2}\right)$ with a density of $2 \mathrm{~g} / \mathrm{cm}^{3}$ was used to concentrate fraction with pollen (in organic rich ring), spores and other organic particles. The microscope slides were prepared using glycerin as a mounting medium, and one to three slides per sample were examined by Axioscope Zeiss with magnification 40x and 63x. Photos were taken using AxioCamERc5s under the 63x magnification. Pollen spectra were statistically visualized and treated using Polpal software (Nalepka and Wallanus, 2003). 


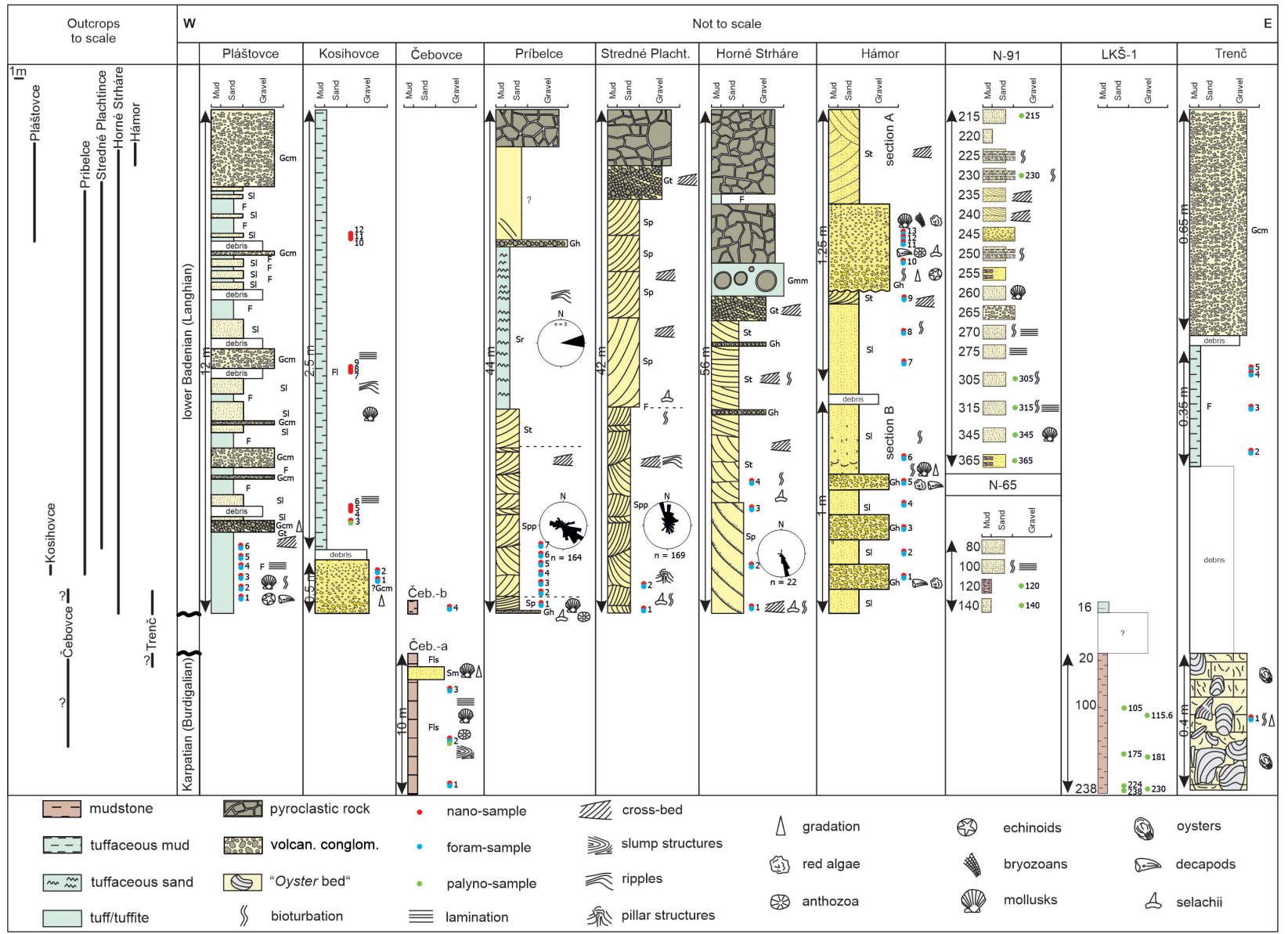

FIGURE 2. Lithology of the studied sections with sedimentological logs and paleoflow orientation. For codes of lithofacies see Appendix 1.

Conventional $\mathrm{C}$ and $\mathrm{O}$ isotope analysis was performed by using GasBench II (ThermoFisher Scientific) equipped with a CTC Combi-Pal (PALSYSTEM) autosampler and linked to a MAT253 isotope ratio mass spectrometer (ThermoFisher Scientific) in a Continuous Flow IV (ThermoFisher Scientific) system at the Charles University in Prague. The internal precision (SD) measured over these six peaks is typically 0.02 and $0.09 \%$ for raw $\delta^{13} \mathrm{C}$ and $\delta^{18} \mathrm{O}$ values, respectively, given a sample size above $50 \mu \mathrm{g}$. Calibration of the raw results versus the V-PDB scale is achieved using in-house calcite standards (subsequent to linearity correction) that have been calibrated against NBS-18, LSVEC and IAEA-603 international reference materials (IAEA, Vienna, Austria). Stable carbon and oxygen isotopes were studied on the tests of Globigerina sp. div. (surface water marker), Cibicidoides sp. div. (bottom water marker) and Melonis pompilioides (sediment pore water marker). The Melonis data can be served only for the Burdigalian because the taxon does not occur in sufficient quantity in the Langhian sections.

\section{LITHOLOGY AND FOSSIL CONTENT OF THE STUDIED SECTIONS}

The Čebovce outcrop (Figures 2, 3) is 10 meters high, facially monotonous and consists of mudstones ranked to the Sečianky Member (Vass, 2002). The section starts by layered, faintly laminated mudstone with soft sediment deformations and common marine fossils (Fls - lithofacies; Appendix 1). Next thick fine to coarse, occasionally pebbly sandstone layer follows and yields abundant casts of mollusks. In the northernmost part of the section mudstones facies continue. Calcareous nannoplankton is common to very abundant and dominated by Coccolithus pelagicus, Reticulofenestra haqi and Sphenolithus moriformis (Appendix 2). The palynological study has found only gymnosperms: bisaccate Pinus and Abies. The nonpollen palynomorphs are represented only by 

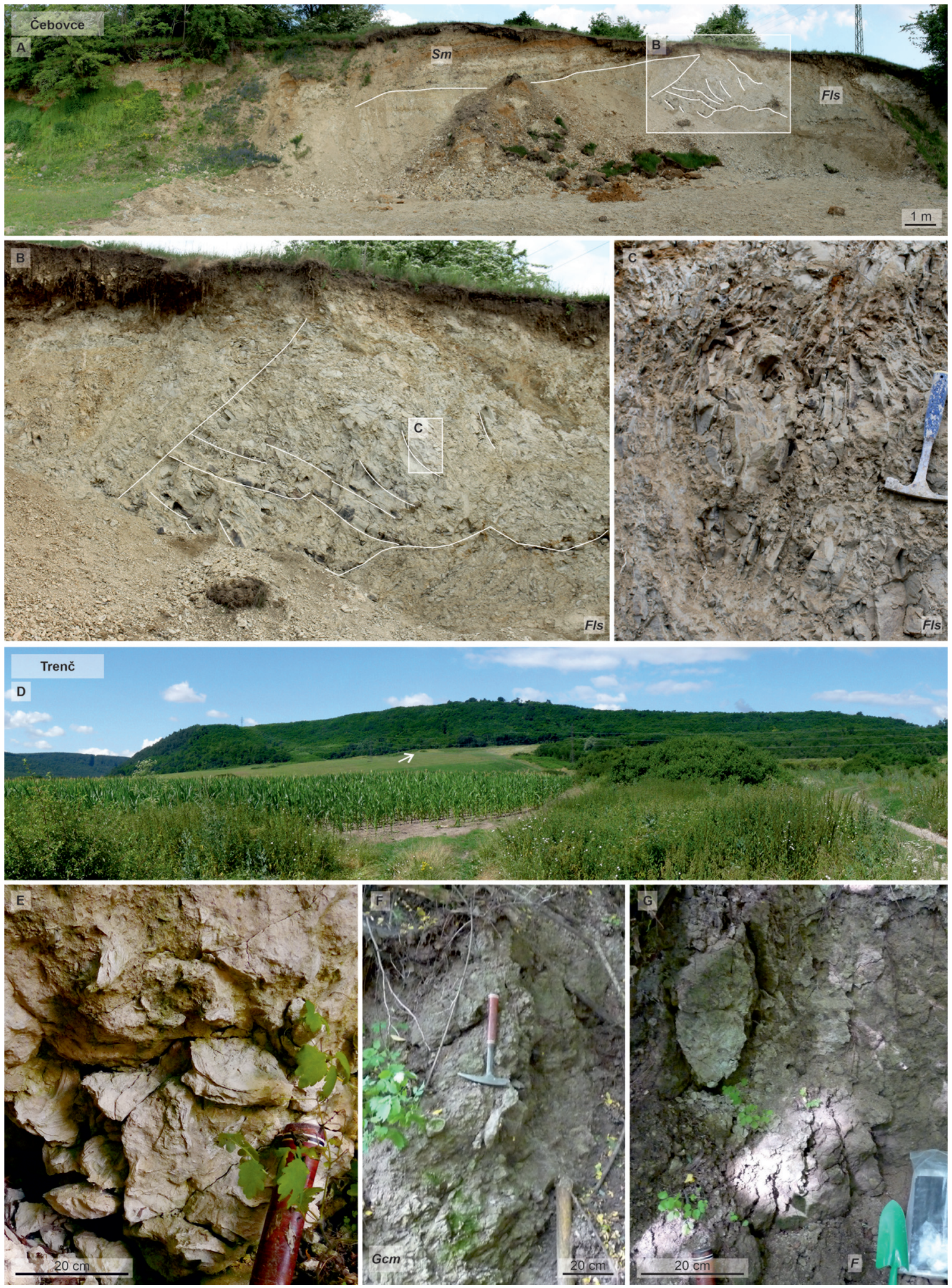

FIGURE 3. Photoplate of the Čebovce and Trenč sections: A-C. Čebovce section, lat. 48 $11^{\prime} 17.88^{\prime \prime} \mathrm{N}$, lon. $19^{\circ} 13^{\prime} 38.94 " E$, mud with faint lamination with slump bodies overlain by fine to coarse grained sand with pebbles. DG. Trenč section, lat. $48^{\circ} 13^{\prime} 20.47^{\prime \prime N}$, lon. 19¹4'44.42"E. D) Southern foot of the Strážna hora hill with oyster reefs outcropping at the forest boundary. E) Ostrea bed. F) Clast supported massive gravels. G) Fine-grained tuffite. For codes of lithofacies marked in italic see Appendix 1. 
the Botryococcus braunii algae (Appendix 4). Washed residua rich in microfossils are markedly dominated by globigerinid foraminifers Ciperoella concinna, C. ciperoensis, Turborotalita quinqueloba and Globigerina regularis. In the benthic fauna, Hoeglundina elegans, Bulimina div. sp. and Bolivina div sp. are frequent. $\delta^{18} \mathrm{O}$ values range from -0.5 to $-1.3 \%$ for Cibicidoides and from -0.5 to $-1.8 \%$ for Globigerina in the section Čebovce (a). In this section $\delta^{13} \mathrm{C}$ range from -0.4 to $-0.8 \%$ for Cibicidoides and from 0 to $-0.8 \%$ for Globigerina thus, they partially overlap. $\delta 180$ in the Melonis pompiloides tests vary from -0.2 to $-0.5 \%$ for Čebovce (a) section, $\delta^{13} \mathrm{C}$ values range from -0.3 to $0.2 \%$. Rich diatom assemblages are dominated by Actinoptychus splendes (Shadbolt) Ralfs, Triceratium aff. favus Ehrenberg, and T. favus Ehrenberg.

Čebovce (b) section is an additional sample taken from the uppermost part of the section, which contain common to very abundant calcareous nannoplankton dominated by Coccolithus pelagicus, Reticulofenestra haqii, Helicosphaera carteri and Pontosphaera multipora. Discoasters were also observed within this section. The foraminiferal assemblage contains a diversified fauna with Globorotalia archeomenardii, Uvigerina graciliformis and Lenticulina cf. echinata.

The Trenč (Figures 2, 3) site was first mentioned by Čechovič and Seneš (1950). Today the outcrops are scattered in up to $2 \mathrm{~m}$ wide forest gutters. At the base, limestones dominate and yield articulated Ostrea shells which become fragmented higher up. The Ostrea beds pass into tuffaceous mudstones with faint layering $(F)$. Above, clast supported massive gravels with indistinct normal gradation $(\mathrm{Gcm})$ follow. The pebbles are mostly composed of volcanic rocks (up to $\sim 10 \mathrm{~cm}$ in diameter). These sediments are almost entirely barren of calcareous nannoplankton and diatoms. Preservation of nannofossils is poor, only dissolution resistant species occur (Coccolithus pelagicus, Watznaueria sp.). In the oyster bed planktic foraminifera are rare, Ammonia parkinsoniana and Pararotalia calcariformata strongly dominate together with other epiphytic taxa like Cibicidoides lobatulus and Biasterigerina cf. planorbis. Residuum from the mudstones yield badly preserved foraminiferal rests often present as calcite casts, mostly without original calcite wall, planktic Globigerinoides (Trilobatus) group prevails. Praeorbulina is present as molds and test fragments, Globorotaliids ( $G$. bykovae and $G$. transsylvanica) are common. Benthic foraminifera are represented by casts of lagenids and miliolids. Uvigerinids are rare (Uvigerina cf. macrocarinata, Nodosaria sp). Higher up (sample 6; Figure 2) symbiont bearing miliolids (Borelis melo, Peneroplis pertusus) and quinqueloculinids prevail.

The facies, fauna and flora of the Kosihovce (Figures 2,4 ) section were previously studied by Hano (1950), Vass et al., (1979) Vass (1989) and Holcová (2001). Today the section is located in an abandoned quarry. It is discontinuous and approximately $2.5 \mathrm{~m}$ high and $4 \mathrm{~m}$ wide. Fine-grained tuffaceous sands with faint lamination and ripples commonly yield marine fossils (FI). These sediments are underlain by clast supported massive gravels with indistinct normal gradation (?Gcm). Calcareous nannoplankton is abundant, Coccolithus pelagicus slightly dominates (30-60\%), Helicosphaera carteri and Reticulofenestra haqi are common. Reworked Oligocene species are rare, Cretaceous ones occur in only a few samples. Poriferan spicules are very abundant. Foraminiferal tests are poorly preserved and bear signs of dissolving and abrasion. Planktic assemblage dominates by Trilobatus trilobus and Ciperoella ciperoensis. Benthic assemblage is significantly more diversified and is composed from Nonion communis, Cassidulina laevigata, Hansenisca soldanii, Bolivina sp. div., Porosonion granosum, Ammonia parkinsoniana and cibicidids. The mudstones contain diversified pollen spectra, dominated by various bisaccate pollen grains (Pinus, Cathaya, Picea, and Abies) accompanied by Botryococcus braunii algae and prasinophyts. Rarely, Corrugatisporites bot. aff. Lygodiaceae, Lygodium, Fagaceae - Quercoideae, Platycarya, Engelhardia, Momipites, Castanea/Castanopsis, Carya and Sapotaceae are present.

The Pribelce (Figures 2, 4) section is the type locality for the Príbelce sand member and was previously studied by Vass (1977), Vass et al. (1979) and Vass (2002). The outcrop is situated in an occasionally mined sand pit positioned west from the Horné Pribelce village. The exposed wall is about $50 \mathrm{~m}$ high and $\sim 200 \mathrm{~m}$ wide. The Príbelce section starts with a $5-20 \mathrm{~cm}$ thick horizontally bedded clast supported gravel with sandy matrix and marine fauna (Gh). It continues with a $\sim 1 \mathrm{~m}$ thick, north east dipping, grouped, planar, unidirectional, cross-beded sand, which contain bioturbations, mud drapes and marine fauna and flora (Sp). Above, a $\sim 12 \mathrm{~m}$ thick packet of grouped, planar, bidirectional, sandy cross-beds is present. Each individual bed is about $15 \mathrm{~cm}$ thick. Bioturbations, mud drapes and marine fauna and flora is com- 

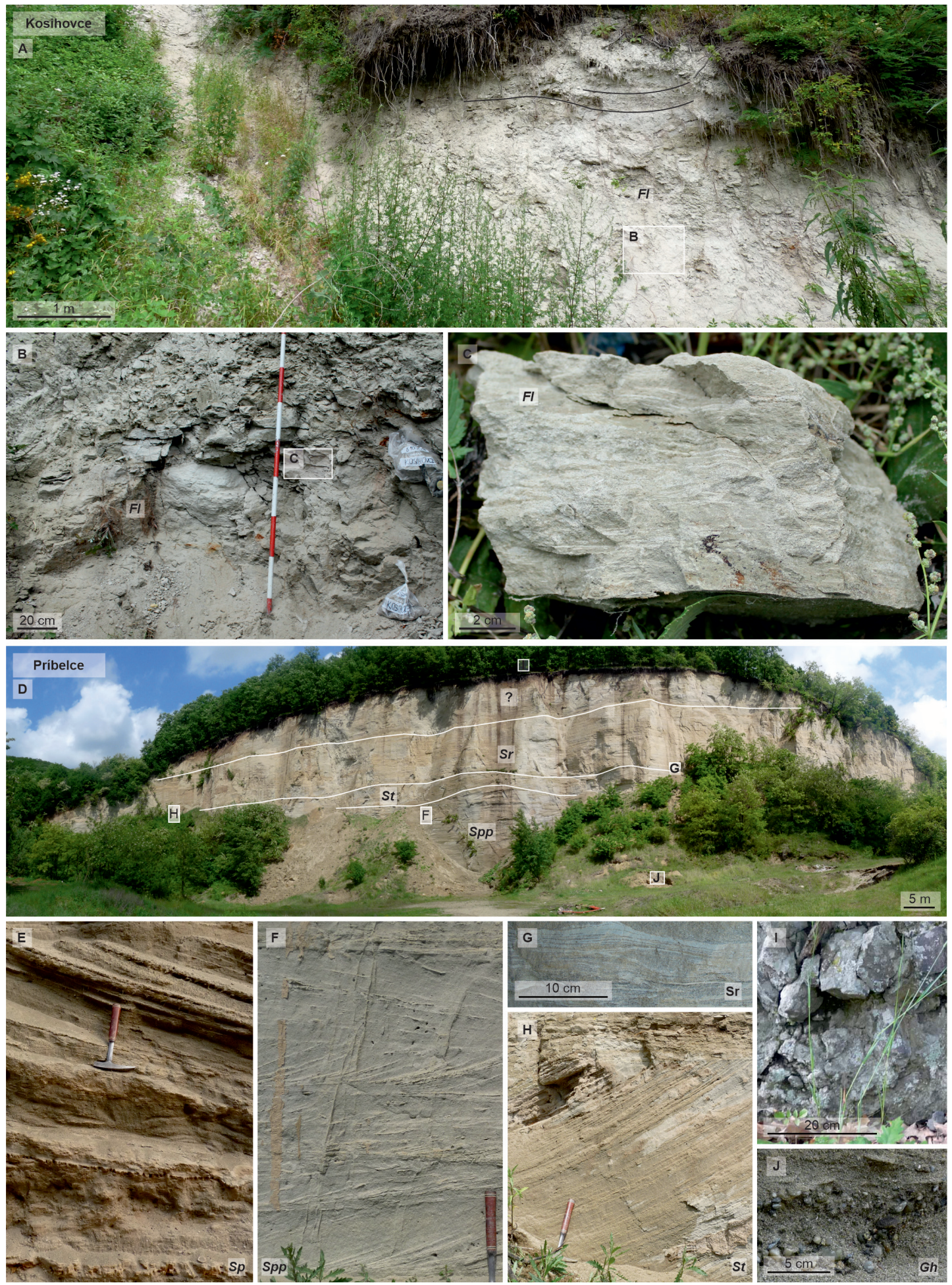

FIGURE 4. Photoplate of the Kosihovce and Pribelce sections: A-C. Kosihovce section, lat. 48 $11^{\circ} 15.16^{\prime \prime} \mathrm{N}$, lon. $19^{\circ} 31^{\prime} 35.74 " E$. A) Fine-grained tuffites with faint lamination and symmetrical ripples. B) Detail of the sampling points. C) Fine-grained tuffite with faint lamination. For codes of lithofacies marked in italic see Appendix 1. D-J. Príbelce section, lat. $48^{\circ} 11^{\prime} 49.89 " \mathrm{~N}$, Ion. $19^{\circ} 14^{\prime} 44.42 " \mathrm{E}$. D) Type locality of the Pribelce Member, E) Fine to very coarse sand with grouped unidirectional cross-beds. F) Fine to very coarse sand with grouped bidirectional cross-beds, G) Detail of the symmetrical ripple composed of sand and tuffite. H) Grouped unidirectional trough cross-bedded sand. I) Pyroclastic breccia. J) Fossiliferous horizontally bedded clast supported gravels with sandy matrix. For codes of lithofacies marked in italic see Appendix 1. 
mon. Main dip of the beds is towards the SE, and the less pronounced dip is towards the NW (Spp). Higher up another packed (3.5 m thick) of east dipping unidirectional sandy trough cross-beds follows. Individual beds are about $0.6 \mathrm{~m}$ thick (St). These beds are followed by a $12 \mathrm{~m}$ thick layer of laminated tuffaceous sands which yields symmetrical ripples (Sr). The top of these beds is erosive and overlain by a horizontally bedded clast supported gravel with sandy matrix. The layer occasionally yields cobble and boulder size clasts of volcanic rocks (Gh). The following beds are $\sim 8 \mathrm{~m}$ thick, and part of the main section remains enigmatic due to its unreachable position within the section. The topmost part of the section is exposed in the forest located above the main section and yields a $2 \mathrm{~m}$ thick patch of pyroclastic brecciass.

The washed residuum from the studied samples is composed mainly of poriferan spicules, pteropods, ostracod valves and echinoid spines. Planktic foraminifera like Ciperoella ciperoensis and Globigerina praebulloides (=Globigerinella obesa) are rare and fragmented. The foraminiferal assemblage is dominated by benthic forms; tests are abundant, but not well preserved. Cibicids (Hanzawaia boeueana, C. refulgens and C. pachyderma) are the most dominant and well preserved. Bulimina schischkinskayae, Bolivina cf. plicatella and Nonion commune are common. In the lower part of the section, nannoplankton assemblage includes Coccolithus pelagicus and Reticulofenestra haqii. Diatoms are rare, Cretaceous and Paleogene redeposit also occur. Sediments in the middle part of the section are barren for calcareous nannoplankton. In the upper part Reticulofenestra haqi dominates over Coccolithus pelagicus. Oligocene redeposits are abundant.

The Stredné Plachtince (Figures 2, 5) section is correlated with the Pribelce sand member (Vass, 1977; Vass et al., 1979). It is located in an actively mined sandpit situated on the eastern margin of the Stredné Plachtince village. The section begins with a $16 \mathrm{~m}$ thick packet of fossiliferous, bioturbated, bidirectional, planar sandy cross-beds with abundant mud drapes. Individual beds are about $15 \mathrm{~cm}$ thick and yield pillar structure and symmetrical ripples. The major dip is towards the north, and the secondary dip is towards the south (Spp). Above an $8 \mathrm{~m}$ thick unidirectional sandy cross-bed follows and dips towards the south (Sp). In the overburden multiple large-scale cross-beds ( 10 m thick) are present and dip towards the south-east $(\mathrm{Sp})$. They are overlain by multiple beds (together about $3 \mathrm{~m}$ thick) of unidirectional, clast supported, trough cross-bedded gravels with erosional bases (Gt). The section ends with packet pyroclastic breccias (5 $\mathrm{m}$ thick). Microfauna and nannoflora are absent, only sporadic finds of mollusks and shark teeth (Carcharias sp.) were recorded.

The Horné Strháre (Figures 2, 5) section was described as a part of the Pribelce sand member (Vass, 1977; Vass et al., 1979). Locality is situated in an occasionally mined sand pit positioned west from the Horné Strháre village. The outcrops are spread throughout six quarry levels, and the section is about $54 \mathrm{~m}$ high and $\sim 250 \mathrm{~m}$ wide. The section begins with a $12 \mathrm{~m}$ thick coarse-grained, fossiliferous, large scale, unidirectional, south dipping, planar, sandy cross-bed, with bioturbations and mud drapes (Sp). It is followed by a $21 \mathrm{~m}$ thick packet of medium to fine-grained, grouped, unidirectional, trough cross-bedded sands with mud drapes. The dip of the cross-beds is scattered between the south and west (St). The packet also includes rare $1-5 \mathrm{~cm}$ thick horizontally bedded, clast supported gravels with sandy matrix (Gh). A 3 $\mathrm{m}$ thick layer of clast supported through cross-bedded gravel follows. It is covered by a matrix supported paraconglomerate (clasts reach up to $1.5 \mathrm{~m}$ in diameter) with tuffaceous ground mass ( $\mathrm{Gmm}$ ). The section ends with a $14 \mathrm{~m}$ thick interval of pyroclastic breccias intercalated by tuff and tuffites. Microfauna and nannoflora were not recorded. However, abundant vertebrate fossils occure: Odontaspis cuspidata, O. acutissima, Hexanchus sp., Carcharias priscus, Galeocerdo aduncus, Isurus sp., ?Carcharodon sp., Myliobatidae indet., Actinopterygii indet., Testudines indet., Cervidae indet.

The facies and the fossil content of the Pláštovce (Figures 2, 6) section were originally described by Molčíková (1964), Melioris and Vass (1982), Vass (2002), Sukatcheva et al., (2006) and Hyžný et al. (2015). Today the site is composed of numerous outcrops that are scattered accros the Pláštovce village and vicinity. The studied composite section begins with fine-grained tuffite with faint layering $(F)$. Bioturbation is common, and the layers are rich in marine fauna (echinoids, bivalves, gastropods, decapods). These layers are commonly incised by clast supported through crossbedded gravels and/or by massive gravels (Gt, $\mathrm{Gcm}$ ). These are overlain by fine- to coarsegrained sands with faint low angle lamination (SI). This lithofacies association repeats rhythmically through the whole section. In the tuffites abundant Ophiomorpha trace fossils, composed of vertical shafts with a circular cross section and horizontal 

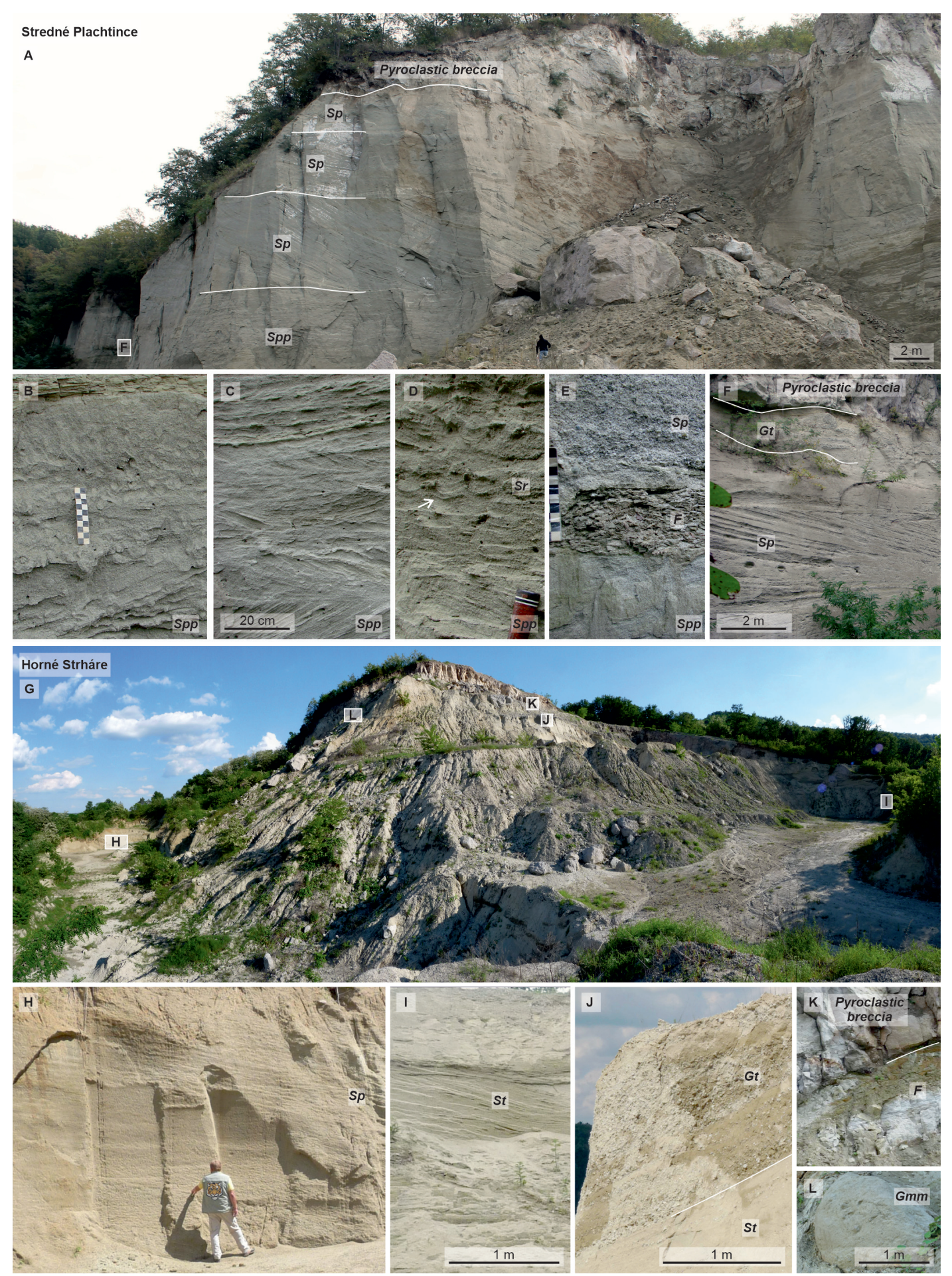

FIGURE 5. Photoplate of the Stredné Plachtince and Horné Strháre sections: A-F. Stredné Plachtince section, lat. $48^{\circ} 13^{\prime} 20.69^{\prime \prime N}$, lon. $19^{\circ} 18^{\prime} 18.54 " \mathrm{E}$. A) Main quarry wall exposing Príbelce sand topped by pyroclastic breccias. B-C) Bioturbated grouped bidirectional planar cross-bedded sand. D) Sand with symmetrical ripples marked by arrow. E) Contact between bidirectional and unidirectional cross-beds marked by tuffite layer. F) Contact between unidirectional cross-beds and through cross-bedded gravels topped by pyroclastic breccias. G-K. Horné Strháre section, lat. $48^{\circ} 15^{\prime} 57.91 " \mathrm{~N}$, lon. $19^{\circ} 21^{\prime} 9.08^{\prime \prime} \mathrm{E}$. G) Overall view of the quarry. H) unidirectional planar sandy cross-beds. I) Trough cross-bedded sand with mud drapes. J) Contact between trough cross-bedded sand with mud drapes and clast supported through cross-bedded gravels. K) Contact between tuffites and pyroclastic breccias. L) Boulder-sized clast of the paraconglomerate facies. For codes of lithofacies marked in italic see Appendix 1. 

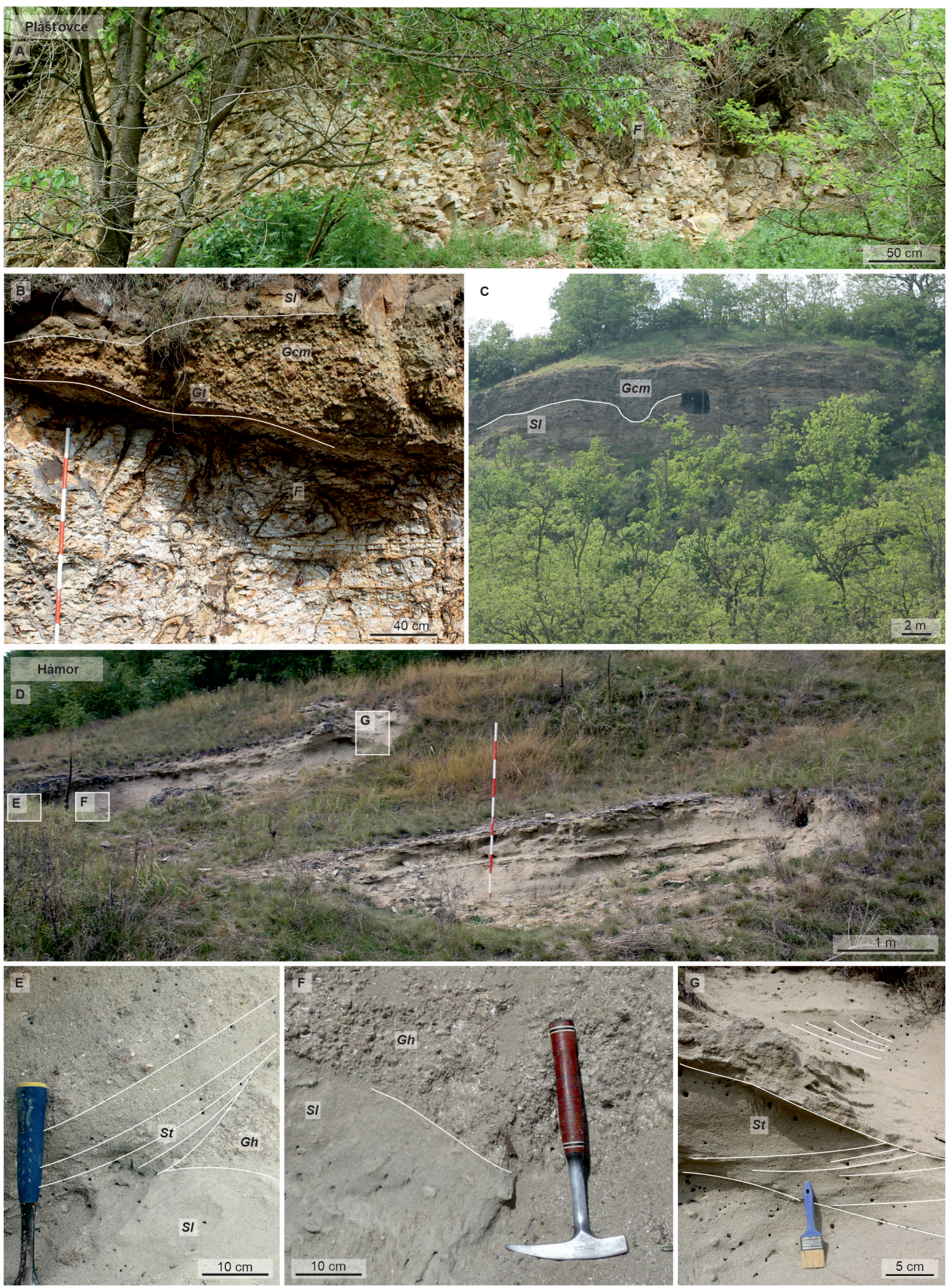

FIGURE 6. Photoplate of the Pláštovce and Hámor sections: A-C. Pláśt'ovce section. A) lat. $48^{\circ} 9^{\prime} 23.53^{\prime \prime} \mathrm{N}$, lon. $18^{\circ} 57^{\prime} 26.67 " \mathrm{E}$, fine grained tuffites. B) Lat. $48^{\circ} 9^{\prime} 14.61^{\prime \prime}$, lon. 18 $56^{\prime} 47.80^{\prime \prime}$, clast supported through-cross bedded gravels overlying fine grained tuffites. C) Lat. $48^{\circ} 9^{\prime} 28.24^{\prime \prime} \mathrm{N}$, lon. $18^{\circ} 57^{\prime} 28.60 " \mathrm{E}$, main quarry wall exposing fine to coarse grained sand, clast supported massive gravels. D-G. Hámor section, lat. 48 $18^{\circ}{ }^{\prime} 51.66 " \mathrm{~N}$, lon. 19³1'35.74"E, D) Overall view of the outcropping sand. E-G) Alteration of through cross-bedded low-angle laminated sands and clast supported gravels with sandy matrix. 
tunnels occurred, complete crab exoskeletons are also preserved. Foraminiferal tests are rare, some samples yield molds of Globigerina sp., Nodosaria $\mathrm{sp}$. and Bulimina elongata.

The Hámor (Figures 2, 6) site was first mentioned by Čechovič and Seneš (1950) and later by Vass et al. (1979). It is located NE from the Hámor village. The section consists of two parts, section $A$ and section $B$, and both are about $1 \mathrm{~m}$ high and $\sim 20 \mathrm{~m}$ wide. Section B consists of two facies types which repeat rhythmically. The first type consists of fine to coarse occasionally pebbly sandstones (SI); the second type is represented by horizontally bedded clast supported gravels with sandy matrix which yield abundant marine fauna and flora (Gh). Section A includes the mentioned facies (SI) and (Gh), but also includes bioturbated, unidirectional trough cross-bedded sands (St). Calcareous nannoplankton (Figure 7, Appendix 2) is very rare except for two samples where Reticulofenestra minuta dominates. Dinoflagellate Thoracosphaera $\mathrm{sp}$. was also documented and is very abundant in section $A$. The washed residua contain poriferan spicules and rhaxi, bivalve shells, echinoid spines and plates, ostracod shells, bryozoans, serpulids, fish teeth and fish bones as well. Foraminifera (Figure 8, Appendix 3) show strong secondary calcification which covers the original ornamentation of the test and hides the chamber organization. Assemblages are diversified and benthic taxa strongly prevail (Figure 9). The epiphytic group (e.g., Asterigerina sp., Hanzawaia boueana, Cibicidoides lobatulus, high spiral Ammonia parkinsoniana, Textularia sp.) dominates throughout the whole section with the most prevalence in samples Hámor-10 and 13 (Appendix 3). Within the planktic forms, Globigerinoides/Trilobatus group is dominant.

\section{Lithology and Fossil Content of the Studied Wells}

Studied sections were complemented by several wells (LKŠ-1, N-65, N-80, N-91), which penetrated sediments synchronous to those studied in the sections. Sediments of the Pribelce member were found only in the $\mathrm{N}-80$ well. They consist of massive tuffitic sandstone to siltstone bodies in a thickness of about $100 \mathrm{~m}$. Fragments of pumice stone with a bubble-like structure dominate the washed residue. They do not contain any organic content. This is probably the delta sediment described by Vass (1977). The most common lithotype of the well cores is fine-grained sandstone to siltstone with layers of coarser sand, shell frag- ments and mica scales. Bioglyphs with domichnia are characteristic of being filled with coarser material (N-91, N-65). Cross-bedding occasionally occur with thin clay lenses (dimensions 0.5 to $1 \mathrm{~cm}$ $x 3$ to $10 \mathrm{~cm}$ ), and very rarely gradation layering occurs (gradation layers have a thickness of up to $3 \mathrm{~cm}$ and grain size range from coarse to fine sandstone). The breccias with sharp-edged fragments of pumice material alternate with breccia with oysters at the bottom of the formation $(\mathrm{N}-80)$. Stable carbon and oxygen isotopes were studied in the upper Burdigalian foraminiferal tests obtained from the the LKŠ-1 core (145-165 m); Čebovce section and N83 well (details see Holcová et al., 1996). $\delta^{18} \mathrm{O}$ values range from 0.7 to $-1.4 \%$ for Cibicidoides and from 0.8 to $-1.6 \%$ for Globigerina in the LKŠ-1 core. $\delta^{13} \mathrm{C}$ values are slightly higher for Cibicidoides in this core and range from 0.1 to $1.1 \%$ in comparison with -0.4 to 0.4 for Globigerina. $\delta^{180}$ in the Melonis pompiloides tests vary from -0.6 to $0.6 \%$.

The lower Badenian (Langhian) plankton and benthos isotopic values are: $\delta^{18} \mathrm{O}$ range from 0.5 to $0 \%$ for Cibicidoides and from -1.7 to $-2.3 \%$ for Globigerina; $\delta^{13} \mathrm{C}$ ranging from 0 to $-0.5 \%$ for Cibicidoides and from -1.1 to $-2.5 \%$ for Globigerina (Figure 9Fa-c).

\section{INTERPRETATION AND DISCUSSION OF BIOSTRATIGRAPHY}

The stratigraphic correlation relies on 79 studied microsamples (Figure 2). Planktic foraminifera and calcareous nannoplankton enabled to distinguish four stratigraphic levels (Figures 1, 2).

(1) Burdigalian: NN4 Zone with Helicosphaera ampliaperta, Sphenolithus heteromorphus and Trilobatus bisphericus together with absence of Praeorbulina were determined in the Čebovce (a) locality. The presence of local stratigraphical markers $T$. bisphericus and Uvigerina graciliformis (Cicha et al., 1998; Cicha et al., 2003) allow us to rank the site into the upper Burdigalian (Karpatian) stage.

(2) Langhian: uppermost part of the NN4 Zone with Helicosphaera ampliaperta, $\mathrm{H}$. waltrans (as mentioned in Švábenická, 2002; Holcová et al., 2018), accompanied with $H$. walbersdorfensis, Sphenolithus heteromorphus, Discoaster exilis, $D$. variabilis, $D$. petaliformis and together with Globorotalia archeomenardii, Uvigerina graciliformis and Lenticulina cf. echinata is observed within Kosihovce lowermost part and Čebovce (b) sections. 
PALAEO-ELECTRONICA.ORG
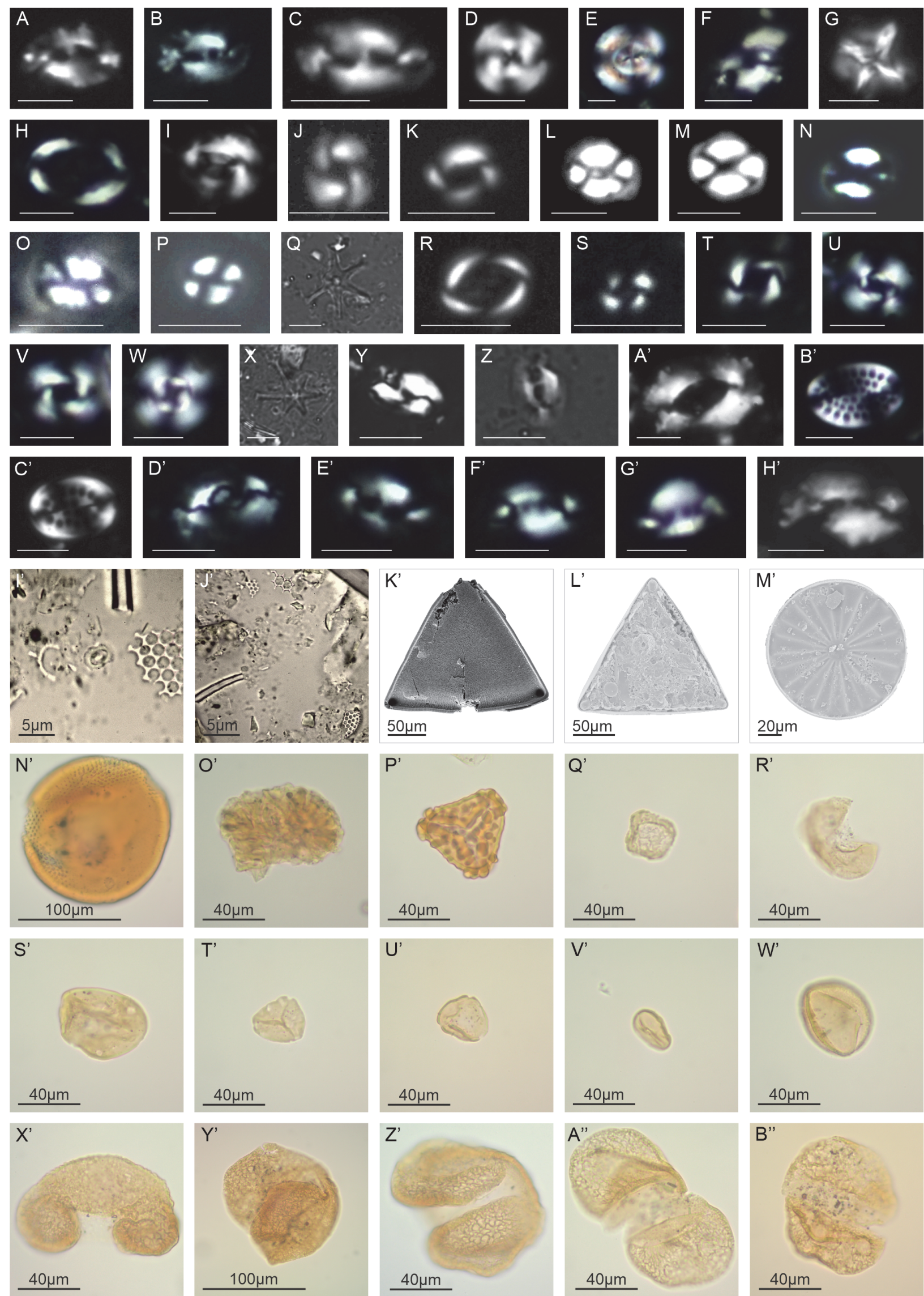
(3) Langhian: NN5 Zone with planktic foraminiferal species Praeorbulina circularis and $T$. bisphericus together with the absence of Orbulina sp. in the Kosihovce, Pribelce and Trenč sections indicate the lowermost Badenian (lower Langhian) age. These sediments were ranked into the regional lower Badenian substage (sensu Hohenegger et al., 2014). Co-occurrence of $P$. circularis (14.9 Ma) in the Mediterranean ( $\mathrm{Di}$ Stefano et al., 2008) together with $H$. waltrans (LCO 14.357 Ma in the Mediterranean; Abdul Aziz et al., 2008) determines the absolute age of these sections to 14.7-14.4 Ma. It agrees with the estimated age of $H$. waltrans event in the Central Paratethys (Holcová et al., 2018; Sant et al., 2020. Presence of $H$. ampliaperta in the Kosihovce section is probably due to reworking, otherwise (based on foraminifera) the coarse sandstones to fine conglomerates of the Kosihovce section would be deposited during the short interval of the uppermost NN4 Zone $(\sim 14.9 \mathrm{Ma})$. Despite the $\mathrm{Sr}$ isotope age of 15.94 Ma (Fordinál et al., 2014; processed on the Oyster valves) the base of the Trenč outcrop was assigned the lower Badenian (Langhian) based on the presence of Pararotalia sp.. However, no other index foraminifers or calcareous nannoplankton was recorded. Regarding $\mathrm{Sr}$ data, there is a discrepancy, whenever we compare the age of $87 / 86 \mathrm{Sr}$ obtained from oyster shells with the age of $87 /$ $86 \mathrm{Sr}$ obtained from foraminiferal shells, mol- luscs or bulk sediment, oyster shells usually give older age (Fordinál et al., 2014; Less et al., 2015; Kováč et al., 2017). Therefore, the Oyster bed age remains questionable. Nonetheless the $\sim 15.9 \mathrm{Ma}$ age cannot be excluded and if considered correct, correlation with Kleinebersdorf localities from lower Austria would be possible (Zuschin et al., 2004).

(4) Late Langhian sediments occur in the Hámor section, which yields an assemblage where the presence of $O$. suturalis and $T$. bisphericus is combined with the absence of both $H$. waltrans and $H$. ampliaperta. This allows correlation of this section into the NN5b-5c Zone (younger than 14.4 Ma).

Biostratigraphic markers have not been found in the Plášt'ovce, Stredné Plachtince and Horné Strháre sections, however, they were stratigraphically correlated based on the similar lihofacies and close proximity to the other sites (Figure 2).

\section{Statistical Analyses}

Only a minority of the calcareous nannoplankton assemblages was suitable for statistical treatment (Figure 9, Appendix 2). Nannoplankton was not recorded in approximately half of analyzed samples (in 35 from 79 samples). Very abundant assemblages were obtained from the Čebovce section. In sections Hámor, Kosihovce, Príbelce and Pláštovce the horizons with common to abundant nannoplankton assemblages alternate with layers nearly barren of calcareous nannoplankton.

FIGURE 7 (on previous page). Photoplate of the nannofossils, diatoms and pollen. A-K. Kosihovce site (NN5a Zone); scale bar equals $5 \mu \mathrm{m}$. A-C) Helicosphaera waltrans Theodoridis, 1984. D) Cyclicargolithus floridanus (Roth and Hay, in Hay et al., 1967) Bukry, 1971. E) Cyclicargolithus abisectus (Muller, 1970) Wise, 1973, reworked Oligocene. F) Helicosphaera recta (Haq, 1966) Jafar and Martini, 1975, reworked Oligocene. G) Micula staurophora (Gardet, 1955) Stradner, 1963, reworked Upper Cretaceous. H) Pontosphaera latoculata (Bukry and Percival, 1971) Perch-Nielsen 1984, reworked Oligocene. I) Reticulofenestra daviesii (Haq, 1968) Haq, 1971, reworked Oligocene. J-K) Reticulofenestra haqii Backman, 1978; L-J'. Čebovce site (NN4 Zone); scale bar equals $5 \mu \mathrm{m}$. L-P) Morphological variability of Coccolithus pelagicus (Wallich, 1877) Schiller, 1930. Q) Discoaster exilis Martini and Bramlette, 1963. R) Coronosphaera mediterranea (Lohmann, 1902) Gaarder in Gaarder and Heimdal, 1977. S) Reticulofenestra minuta Roth, 1970. T) Reticulofenestra haqii Backman, 1978. U-W) Morphological variability of Cyclicargolithus floridanus (Roth and Hay, in Hay et al., 1967) Bukry, 1971. X) Discoaster pentaradiatus Tan, 1927. Y-Z) Helicosphaera waltrans Theodoridis, 1984. A') Helicosphaera ampliaperta Bramlette and Wilcoxon, 1967. B') Pontosphaera multipora (Kamptner, 1948 ex Deflandre in Deflandre and Fert, 1954) Roth, 1970. C') Pontosphaera enormis (Locker, 1967) Perch-Nielsen, 1984; reworked Oligocene. D') Helicosphaera euphratis Haq, 1966. E') Helicosphaera vedderi Bukry, 1981. F'-G') Helicosphaera cf. vedderi Bukry, 1981. H') Helicosphaera carteri (Wallich 1877) Kamptner, 1954. l'-J') Assemblages with coccoliths, centric diatoms and sponge spicules. K') Triceratium aff. favus Ehrenberg, Čebovce site. L') T. favus Ehrenberg, Čebovce site. M') Actinoptychus splendes (Shadbolt) Ralfs, Čebovce site. N') Tasmanites sp., Kosihovce site. O') Botryococcus braunii Kützing, Čebovce site. P') Polypodiaceae indet., Kosihovce site. Q') Ulmaceae indet., Kosihovce site. R') Cupressaceae inet., Kosihovce site. S') Carya sp., Kosihovce site. T') Juglandaceae indet., Kosihovce site U') Juglandaceae indet., Kosihovce site. V') Castanea sp., Kosihovce site. W') Fagaceae indet., Kosihovce site. X') Abies sp., Čebovce site. Y') Abies sp., Kosihovce site. Z') Pinus sp., Čebovce site. A") Cathaya sp., Kosihovce site. B") Cathaya sp., Kosihovce site. 
PALAEO-ELECTRONICA.ORG
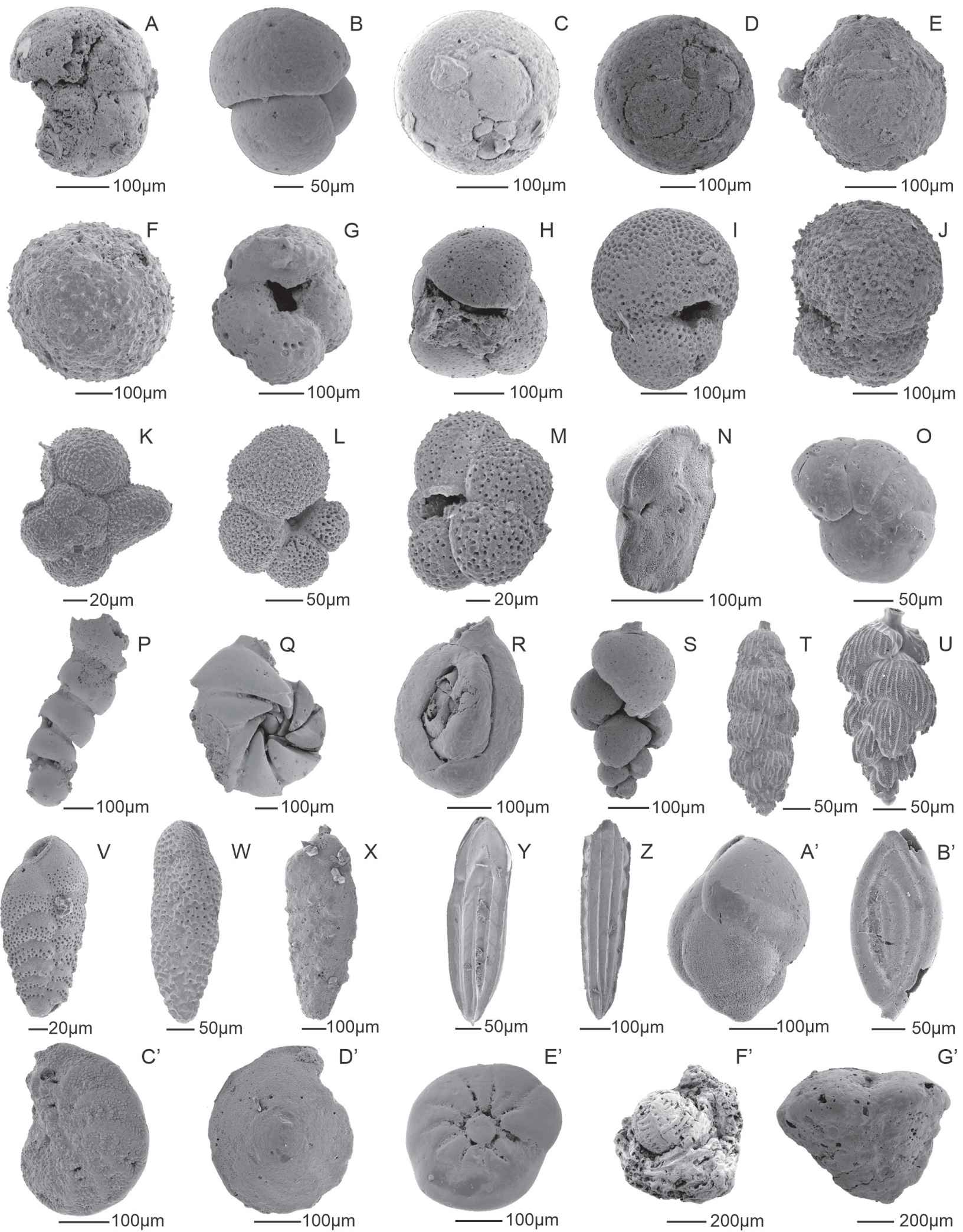
In the Trenč section calcareous nannoplankton was extremely rare and badly preserved. No calcareous nannoplankton was recorded in the Horné Strháre section.

The multivariate statistics was used to identify possible groups of calcareous nannoplankton assemblages. Comparison of results of the following multidimensional methods (PCA, DCA, nMMDS and cluster analysis) gave comparable results and here we presented the most readily outputs (PCA; Figure 9). Two groups of calcareous nannoplankton asssemblages were obtained: (1) homogenous group characterized by abundant Coccolithus pelagicus was recorded in the lower part of the Kosihovce section (Gmg facies), lower part of Pribelce section and mainly Čebovce a section; (2) dispersed group of assemblages dominated by small-sized reticulofenestras which could be further subdivided into three subgroups according to prevalence of (2.1) Reticulofenestra minuta (section Hámor and one sample from section Pláštovce); (2.2) Reticulofenestra haqii (upper part of Pribelce section and Plášt'ovce section); and (2.3) by Thoracosphaera spp. (limestone intercalations from Hámor and Pláštovce section). Specimens of Thoracosphaera spp. were also recorded in the limestones of the Trenč section and in the upper part of the Kosihovce section, but very low nannoplankton abundances in its assemblages do not allow statistical treatment.

Foraminifera were collected from the all studied localities (8 sites). Five of the samples were barren of the foraminifera tests (Trenč 10, 11, 13, Stredné Plachtince, Príbelce). Abundance and species diversity varied between the localities and samples. Preservation of the foraminiferal tests was excellent (Čebovce) to very poor (Hámor). Samples Trenč 1, 4, 5, Hámor 12, Kubáňovo, Kosi- hovce 2, Plášt'ovce 1-6 possessed bad preserved foraminifera, therefore were treated semiquantitatively or qualitatively (Figures 8,9 ).

The following multivariate statistics methods (Cluster analysis, NMDS and DCA) gave us the most readable results and were used for group identification in the benthic foraminiferal assemblage. Cluster analysis using Wards method of clustering shows two distinct groups (Figure 9C). First group (A) consists of Hámor outcrop samples (H6, H11p, H13p, H1p, H 10p), which are dominated by epiphytic foraminifera (Asterigerina cf. planorbis, A. mammilla, Amphistegina sp.) and Shannon_H diversity of benthic assemblages reach from 2.01 to 2.38. The second group (B) comprises all other analyzed samples and can be divided into two sub-groups at distance level 150. In the B1 subgroup assemblages from the Hámor and Kosihovce outcrops dominates (samples H9v, $\mathrm{H} 5, \mathrm{H} 12, \mathrm{H} 2, \mathrm{Ko1}, \mathrm{H} 1$ ); benthic foraminiferal assemblages with average Shannon_H diversity 1.5-2.39 are dominated by Asterigerinata cf. planorbis and Ammonia parkinsoniana; while in the B2 subgroup consists of the samples from Trenč, and Kosihovce Čebovce localities (samples $\operatorname{Tr} 1$, Tr 6p, C1, H7, C2, Ku1, Tr2, Tr 10, Ko2, C-3, Tr4, Tr5), where low Shannon_H diversity (0.6 to 2.2) in foraminiferal assemblages and common infaunal species are observed. Non-metric Multidimensional Scaling (NMDS) confirms dividing into the two main groups (Figure 9) divided by decreasing content of shallow water - epiphytic foraminifers (Borelis, Asterigerinata, Amphistegina) versus increasing content of shallow - to deep infaunal dwellers (Uvigerina, Bolivina). Paleoenvironmental analysis was processed by the Shannon_H and Fisher a ratio (Murray, 2006). Two groups of samples were gained - marsh and brackish marginal

FIGURE 8 (on previous page). Photoplate of the foraminifers. A) Trilobatus bisphericus (Todd, 1954), Trenč 5. B) Trilobatus bisphericus (Todd, 1954), Trenč 6. C) Praeorbulina curva (Blow, 1956), Trenč 5. D) Praeorbulina circularis (Blow, 1956), Trenč 6. E) Praeorbulina circularis (Blow, 1956), Hámor 8. F) Orbulina suturalis Brönnimann, 1951, Hámor 1. G) Dentoglobigerina altispira (Cushman and Jarvis, 1936), Trenč 5. H) Dentoglobigerina altispira (Cushman and Jarvis, 1936), cast, Trenč 5. I) Trilobatus trilobus (Reuss, 1850), Kosihovce 2. J) Trilobatus trilobus (Reuss, 1850), Hámor 8. K) Beella sp. B. cf. praedigitata (Parker, 1967), Čebovce 1. L) Globigerinella obesa (Bolli, 1957), Čebovce 3. M) Turborotalita quinqueloba (Natland, 1938), Čebovce 5. N) Globorotalia archeomenardii Bolli, 1957, Čebovce-b. O) Cibicides crassiseptatus (Łuczkowska, 1960), P) Nodosaria sp., cast, Trenč 1. Q) Lenticulina sp. cast, Trenč 01. R) Cycloforina badenensis (d'Orbigny, 1846), Trenč 1. S) Uvigerina macrocarinata Papp and Turnovsky, 1953, cast, Trenč 1. T) Uvigerina graciliformis Papp and Turnovsky, 1953, Čebovce 5. U) Uvigerina acuminata Hosius, 1895, Čebovce 10. V) Bolivina pokornyi Cicha and Zapletalová 1961, Čebovce 5. W) Bolivina hebes Macfadyen, 1930, Čebovce 10. X) Bolivina dilatata Reuss, 1850, Hámor 13. Y) Plectofrondicularia digitalis (Neugeboren, 1850), Čebovce 10. Z) Plectofrondicularia digitalis (Neugeboren, 1850), Čebovce 10. A') Protoglobobulimina pupoides (d'Orbigny, 1846), Čebovce 5. B') Spirosigmoilina tenuis (Cžjžek, 1848), Čebovce 1. C') Elphidium margaritaceum Cushman, 1930, Hámor 8. D') Heterolepa dutemplei (d'Orbigny, 1846), Hámor 13. E') Ammonia parkinsoniana (d'Orbigny, 1839). F') Borelis melo (Fichtel and Moll, 1798), Hámor 6. G') Sahulia conica (d'Orbigny, 1839), Hámor 11. 

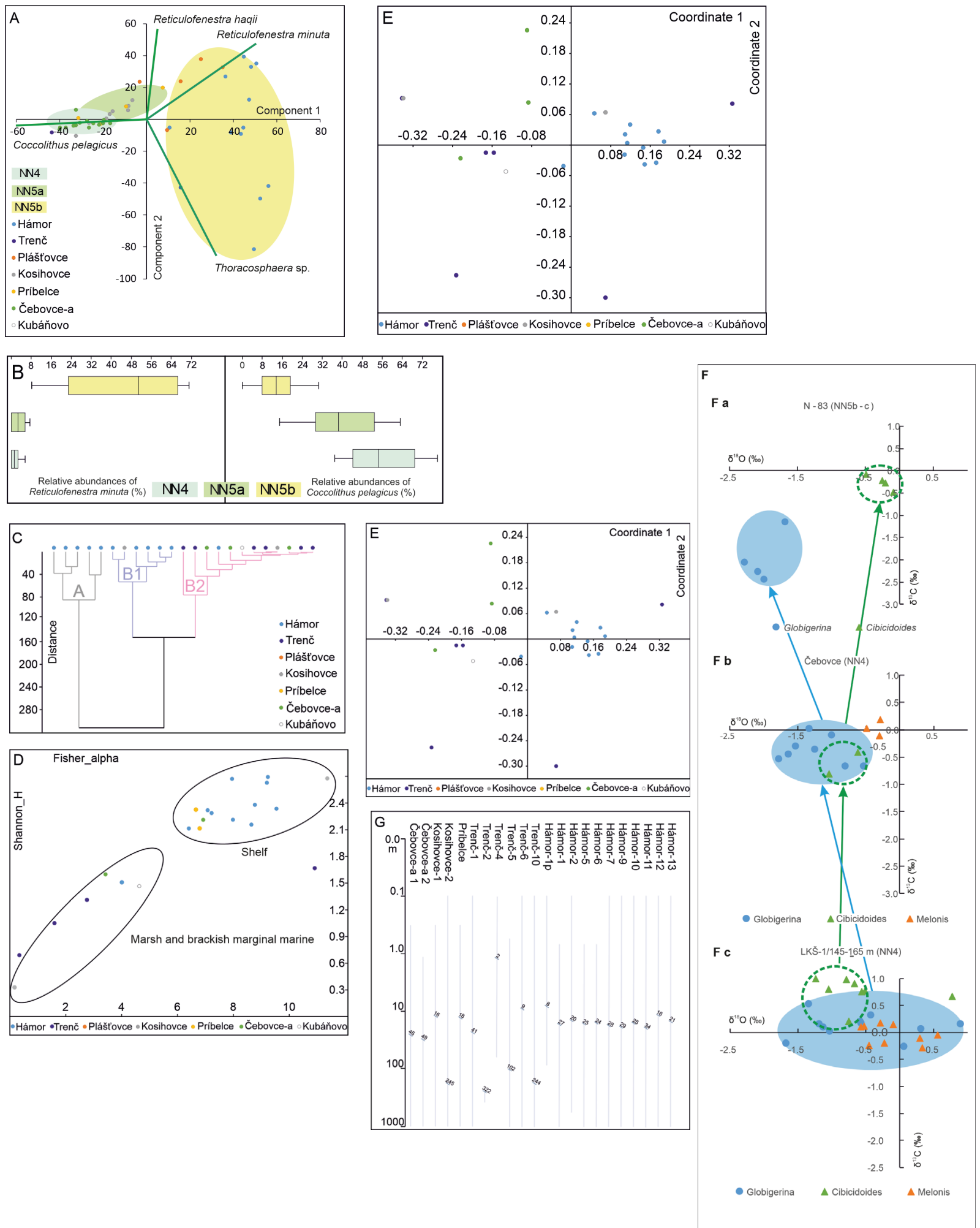

FIGURE 9. Foraminifera and nannofossils - statistical results. A. Principal Component Analysis (PCA) of the nannofossil assemblages. B. Relative abundances of Reticulofenestra minuta and Coccolithus pelagicus in the main stratigraphic levels. C. Cluster diagram (Ward algorithm analysis) of the benthic foraminifera assemblages, D. Species diversity of benthic foraminifera showing relation to typical environment adopted from Murray (2006), E. Non-metric multidimensional scaling (nMDS) diagram of benthic foraminifera, F. Isotope analysis $\left(\delta^{18} \mathrm{O}, \delta^{13} \mathrm{C}\right)$, G. Estimated paleodepths based on benthic foraminifera. 


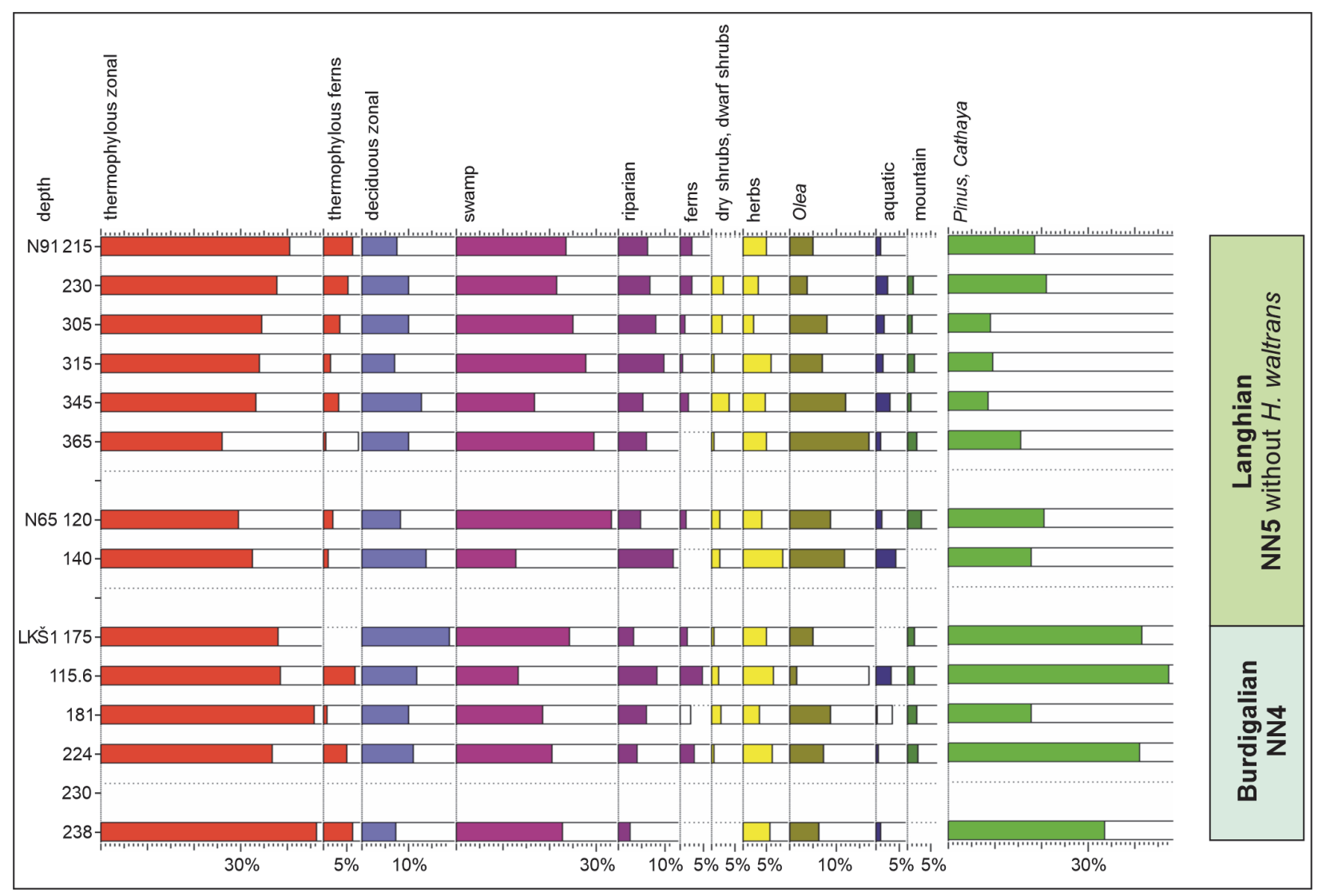

FIGURE 10. Polpal outcome chart - climate and ecology.

marine (Hámor, Kosihovce), and shelfal (Čebovce, Pribelce, Kosihovce, Trenč). Water depth analysis show the deepest marine environment of the studied associations in the Kosihovce 2 (ca $245 \mathrm{~m}$ ) and Trenč $5 \mathrm{~b}$ (ca 102m) localities, while the shallowest are from the Trenč $4(2 \mathrm{~m})$, Trenč $6(9 \mathrm{~m})$ and Hámor $1(8 \mathrm{~m})$ sites. Generally, the estimated water depths reach an average from 2 to $38 \mathrm{~m}$ (Hámor), 8-34 m (Trenč), 38-49 m (Čebovce), 18 $\mathrm{m}$ (Príbelce) and $21 \mathrm{~m}$ (Kosihovce; Figure 9G).

Samples from the Čebovce and Kosihovce localities were only positive for rare palynomorphs due to a very unfavorable sediment for pollen preservation. Pollen analysis of samples from the nearby borehole LKŠ-1 shows the dominance of well diversified bisaccate pollen grains (Pinus, Cathaya, Picea) accompanied by algae Botryococcus braunii and Tasmanites (Figure 10, Appendix 4). In the samples from the borehole LKŠ-1 the paleotropical elements dominate (Sapotaceae, Palmae, Castaneoideae, Cyrillaceae, Araliaceae, Myricaceae, some of Polypodiaceae, less common Rutaceae, Proteaceae). Minor portion of the obtained spectra contain arctotertiary group of flora (Carya, Ulmaceae, Alnus, Juglans, Sciadopitys, together with rare Betula, Celtis, Fagus, Plantago). In the samples from $\mathrm{N}-65$ and $\mathrm{N}-91$ boreholes the swamp flora increase, the lower samples contain the pollens of the wet land vegetation (Polypodiaceae, Selaginella) and aquatic plants Sparganium, ?Potamogeton and Nymphaea as well.

\section{PALEOENVIRONMENT AND PALEOECOLOGY}

The Karpatian (upper Burdigalian) sediments outcropped in the Čebovce locality are composed of faintly laminated mudstones with soft sediment deformations (Fls). This indicates deposition from suspension and subsequent deformation by mass gravity movements. The intercalating massive pebbly sandstones $(\mathrm{Sm})$ were highly likely a product of local debris flows. Both lithofacies are therefore interpreted as the shelf break slope environment (Patruno et al., 2018). Shallow water depth indicated by benthic foraminifera can be explained by redeposition caused due to slumping from the shelf towards the shelf break slope. This claim can be supported by high abundance of planktic foraminifers. An eutrophic environment, typical for upwelling conditions is documented by domination of high-nutrient markers like Coccolithus pelagicus 
(Okada and McIntyre, 1979; Winter et al., 1994; Cachão and Moita, 2000) accompanied by abundant radiolarians, diatoms and acme of Turborotalita quinqueloba (Reynolds and Thunell. 1989; Grunert et al., 2010; Meilijson et al., 2016). Planktic foraminifers in the samples (lack of warm water indicators as Globigerinoides gr.) indicate cool or temperate-cool surface water similar to those in Vienna Basin (Spezzaferri and Čorič, 2001), Styrian basin (Spezzaferri et al., 2009) or Salgótarján Basin (Soron, 2011). Neither nannoplankton nor planktic foraminifera yield warm water associations such as the late Oligocene in this area (Ozdínová and Soták, 2014) and expected in the MMCO. High presence of diatoms in the environment is obviously linked to high nutrient input during cool episodes or upwelling. Besides the high nutrient content, blooms of diatoms can indicate disoluted $\mathrm{SiO}_{2}$ in the basin, most likely of volcanic origin (Baron and Baldauf, 1995; Cermeño et al., 2015). Water rich in nutrients led to microplankton blooming and subsequent decomposition documented in dominance of infaunal foraminifers of Bolivina, Bulimina, Loxostomina and Cassidulina, genera able to withstand dysoxic conditions (Kaiho, 1994; Murray 2006; Meilijson et al., 2016) while the occurrence of oxiphylic Hoeglundina elegans and cibicidoids indicate oxygen decrease within the sediment, hence a oxic/hypoxic boundary in sediment is expected. Similar foraminiferal assemblage is present in the Garáb Fm. in the Salgótarján Basin (Soron, 2011). In the Karpatian (upper Burdigalian), no difference in oxygen isotopic composition of epifaunal and planktic foraminifera (Globigerina vs. Cibicidoides) were observed (Figure $9 \mathrm{Fb}, \mathrm{c}) ; \delta^{13} \mathrm{C}$ in the Melonis pompiloides, tests from the LKŠ-1 core and the Čebovce section are comparable. The lower Badenian (Langhian) plankton and benthos isotopic values are different (Figure 9Fa). Generally, Globigerina $\delta^{18} \mathrm{O}$ values slightly decreased in time, while $\delta^{13} \mathrm{C}$ values stay comparable in the Burdigalian and decrease in the lower Badenian (Figure 9F). Cibicidoides $\delta^{18} \mathrm{O}$ slightly increased from the Burdigalian towards the Langhian, $\delta^{13} \mathrm{C}$ values decrease during Burdigalian and then remain similar. Analogous oxygen isotope values between benthic and planktic foraminifera suggest a mixed water column. However, positive carbon isotope values measured in Cibicidoides tests doubts massive accumulation and decomposition of organic matter at the sea floor. On the other hand, different epifaunal and infaunal isotope values (Cibicidoides div. sp. and Melonis pompiloides) indicate differences between sea- floor and sediment water chemistry that is in agreement with interpretation based on composition of foraminiferal assemblages. Thus lower carbon isotope values are expected for infauna in comparison with epifauna (as we recorded in the LKŠ-1 core). The opposite situation recorded in the Čebovce sections have been documented also from the Middle Miocene of the Carpathian Foredeep. Here, an increase of $\mathrm{pH}$ in sediment is suggested as a reason of this "inverse" carbon isotope values (Scheiner et al. 2018, 2020). The identified pollen spectra represented by paleotropical flora (Palmae, Castaneoideae, Cyrillaceae, Araliaceae, Myricaceae) indicate subtropical climate (Figure 10, Appendix 4). Similar, or even warmer (tropical to subtropical), climate conditions were previously reported from other Karpatian (upper Burdigalian) sediments of south Slovakia (Planderová, 1990; Holcová et al., 1996).

The Kosihovce, Príbelce, Stredné Plachtince, Horné Strháre and Trenč sections are the best examples of sediments correlated with the beginning of the lower Langhian (lower Badenian) stage. In the Príbelce, Stredné Plachtince and Horné Strháre sections, the strata are dominated by unidirectional and bidirectional cross-bedded sands with mud drapes, which intercalate with tuffaceous muds and sand that points to a tide and wave dominated inner shelf (Patruno et al., 2018). Tidal environment can be further supported by the common occurrence of pillar structures (soft sediment deformations) in the Stredné Plachtince (Rossi et al., 2017). These deposits usually pass into clast supported, trough cross-bedded gravels (Gt), which indicate deposition by channelized traction current in downstream migrating channel bars located in the deeper part of a river channel (Miall, 2006). These lithofacies point to a transition from the inner shelf to a delta top or alluvial environment. Outer shelf conditions are expected in the Kosihovce section where the tuffaceous sands and muds yield symmetrical ripples that document tide activity (Rossi et al., 2017) and gravity transport cannot be excluded (Talling et al., 2012). The nannofossil associations from the Kosihovce and Príbelce sections point to transition from high-nutrient $C$. pelagicus (outcrop base) to low nutrient Reticulofenestra haqii assemblages (outcrop top). Abundant diatoms (e.g., Kosihovce 5, Príbelce 1, Appendix 2) together with the planktic foraminifers (G. bulloides, $T$. quinqueloba) confirm temperate to cold water and high nutrient water. The oyster beds in the Trenč are interpreted as patch reef. The overlying tuffaceous muds ( $F$; deposition from suspen- 


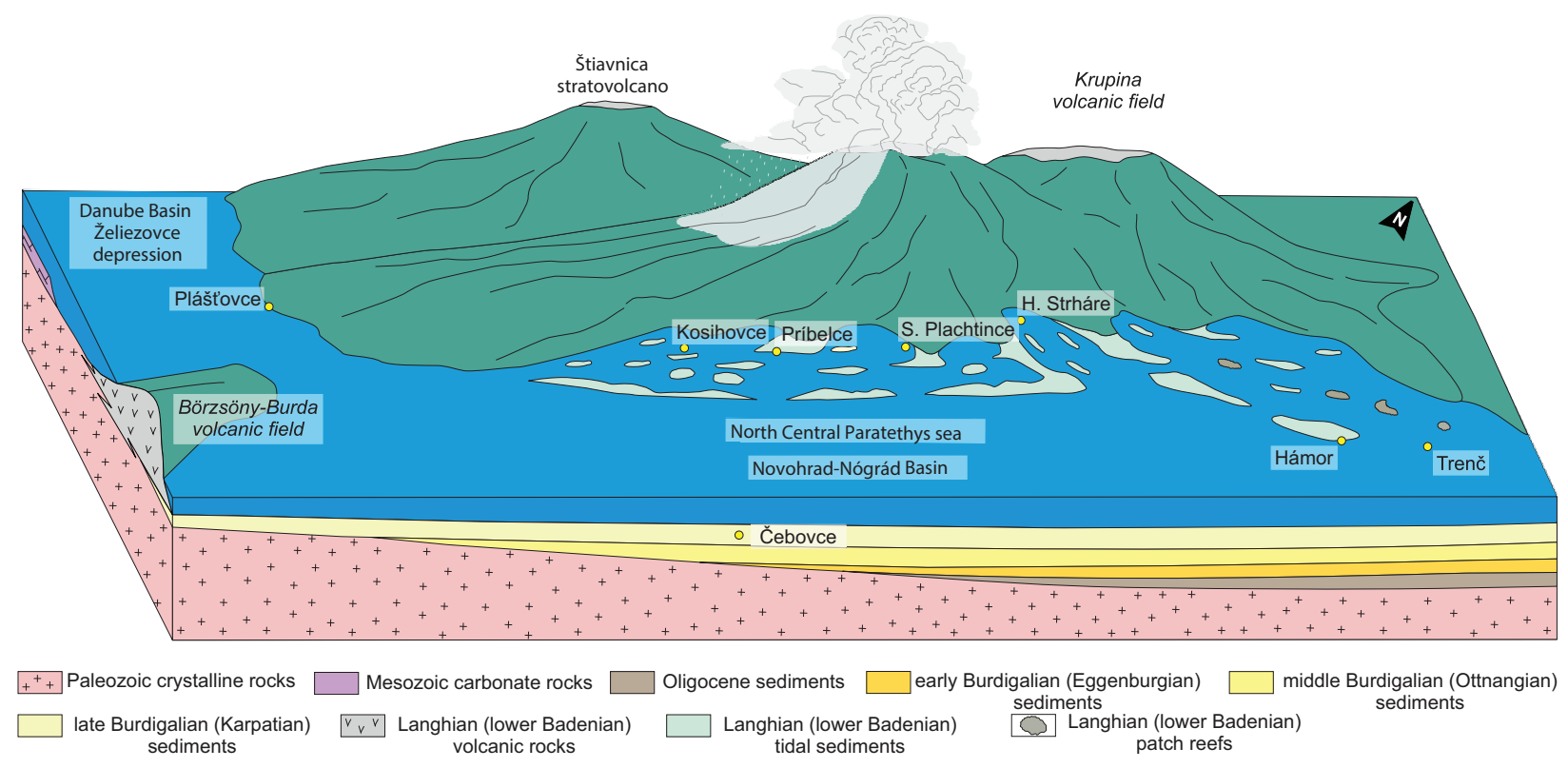

FIGURE 11. Blockdiagram showing paleogeography of the northern Paratethys Sea affected by activity of the Krupina volcanic field during early Badenian.

sion) are connected to the inner shelf environment. Clast supported massive gravels $(\mathrm{Gcm})$ in the overburden point to possible termination of marine conditions. The Trenč section also yields a high portion of Trilobatus sp., which documents warm, low nutrient surficial water (Pearson and Shackleton, 1995; Spezzaferri et al., 2004) that can agree with MMCO culmination. Higher abundance of deep dwelling planktic foraminifera from globorotaliids ( $G$. bykovae and $G$. transsylvanica) point to a slightly deeper water environment in the area (Be and Hutson, 1977; Rupp and Hohenegger, 2008). Benthic foraminiferal association is dominated by cibicids that documents well aerated, shelf conditions (Hansenisca soldanyi, Lenticulina sp., nodosariids). Large, symbiont bearing miliolids (Borelis melo, Peneroplis pertusus) and quinqueloculinids that prevail in the tuffaceous muds $(F)$ of the Trenč section may have been transported from proximal small patch reefs (Figure 11). Decreased rainfalls (aridification) are indicated by increased content of dry shrubs, herbs and Olea pollen within studied associations from the $\mathrm{N}-65$ well. This event may coincide with the Mediterranean aridification dated to $15.01 \mathrm{Ma}$ by Hüsing et al. (2010). Generally, terrestrial environment shows slight climate cooling within the subtropical conditions. Swamps developed along the coast (Cupressaceae, Sciadopytis), and evergreen broadleaved forests are expected in lowlands. Higher altitudes were most likely dominated by pine tree forests (Figure 10, Appendix 4).
During the upper Langhian, deposition continues in the vicinity of the Plášt'ovce and Hámor sections. The fossil assemblage is similar, however, and the depositional environment differs. The Pláštovce section yields fine-grained tuffites $(F)$ deposited from suspension and the intercalating through cross-bedded sands and massive gravels (Gt, Gcm, SI) point to deposition by a channelized and unchannalized traction. Therefore, an alluvial or fan-delta environment is expected (Mial, 2006). Such alteration of marine and terrestrial facies may be explained by close proximity of the Central Slovak Volcanic field (Pécskay et al., 2006), where the expansions and contraction of magma may cause autocyclic bulging before eruptions and rapid subsidence after eruptions (Figure 11). In the Hámor section the pebbly sandstones (SI) were possibly deposited by shallow unchanalized traction that indicates deposition in scours, dunes or antidunes (Miall, 2006). Horizontally bedded clast supported gravels $(\mathrm{Gh})$ indicate wave reworking. The trough cross-bedded sands (St) in section A point to tidal activity within basin-ward migrating tidal channels. These lithofacies point to the inner shelf environment (Patruno et al., 2018) that can be supported by the $20 \mathrm{~m}$ paleodepth estimation derived from the benthic foraminiferal assemblages with dominated epiphytic group (Asterigerina cf. planorbis, Hanzawaia boueana, Cibicidoides lobatulus, high spiral Ammonia parkinsoniana, Textularia sp.) (Figures 8,9$)$. Similar associations of the same age 
are recorded from the Carpathian Foredeep (Studencka, 1994; Studencka and Jasionowski, 2011; Holcová et al., 2015a) and Vienna Basin (Wiedl et al., 2013; Pivko et al., 2017). The sporadic occurrence of planktic foraminifera, which cannot survive in the shallow coastal environment of the Hámor section, could be transported from the central to marginal part of the basin by surface currents that agrees with the anti-estuarine circulation model suggested for Central Paratethys during NN5 Zone (Báldi, 2006; Kováč et al., 2017). The change from estuarine to antiestuarine circulation is supported by a trend of carbon and oxygen isotope values (Figure 9Fa-c). Decreased oxygen isotope values of Globigerina between Burdigalian and Langhian might be related to an increase of surface water temperature after the end of the cold bottom-water uprise. Decreased primary productivity during the Langhian can be supported by the lower carbon isotope values in the tests of Globigerina bulloides (Peeters et al., 2002). Accumulation of the organic matter at the sea floor is questionable due to high carbon isotope values of Cibicidoides tests.

The sediments from the Pláštovce and Hámor sections contain small Reticulofenestra minuta, which tolerate salinity and/or nutrients oscillations (Wells and Okada, 1997; Flores et al., 1997; Kameo, 2002; Wade and Brown, 2006) indicating increased stress in surface waters. Similar calcareous nannoplankton assemblages are typical for the Central Paratethys Langhian sediments (Spezzaferri et al., 2009; Holcová, 2013) and might reflect changes from estuarine to antiestuarine circulation (Kováč et al., 2017; Holcová et al., 2018). Higher abundances of Dentoglobigerina sp. can also document unstable environmental conditions (Keller, 1985; Pearson and Shackleton, 1995). Co-occurrences of large Globigerina bulloides and Globigerinoides (Trilobatus) spp. indicates seasonal changes in water temperature - warmer summer surface water with Globigerinoides and cooler spring water with a bloom of G. bulloides (Kretschmer et al., 2018). Isotope analysis confirms stratification of water column from oxygen and carbon isotopes. Benthic foraminiferal assemblages (e.g., base of the Plášt'ovce section) contain shallow-water oligotrophic Amphistegina sp., epiphytic assemblage Asterigerinata sp., Cibicidoides lobatulus, corroded Cibicidoides sp. indet., and Ammonia sp., tolerating salinity oscillations. Eutrophic conditions with possible hypoxia on the sea floor (or in sediment only) are documented by an increase of Bolivina dilatata and Bulimina elongata. It can reflect both, (1) variegated paleoenvironment (intra-/interannually); or (2) oligotrophic oxic environment at the sea floor locally covered by seagrass meadows with hypoxic sediment in higher nutrient content. The co-occurrence of common epiphytic and rare hypoxic and high-nutrient foraminifera is rather common e.g., in substrate accompanying recent Mediterranean sea-grass meadows where low-oxic environment with high organic matter develops in sediment between Possidonia root system (Borum et al., 2006).

\section{CONCLUSIONS}

In studied sections, four stratigraphic levels were distinguished:

The upper Burdigalian (Karpatian) NN4 Zone with Helicosphaera ampliaperta and Sphenolithus heteromorphus and with Trilobatus bisphericus, Uvigerina graciliformis was identified in high-nutrient facies deposits of shelf break slope in Čebovce section (a).

The upper Burdigalian - lower Langhian (Karpatian? /earliest Badenian 14.9 Ma and older) top NN4/base NN5 Zone with Helicosphaera waltrans, $H$. walbersdorfensis, $H$. ampliaperta, Sphenolithus heteromorphus, Discoaster exilis, $D$. variabilis and $D$. petaliformis were identified in deposits of shelf break slope in Čebovce (b) section and Kosihovce lowermost part.

Langhian (lower Badenian) sediments were divided into two distinct intervals where the presence of the genus Orbulina and absence of both $H$. waltrans and $H$. ampliaperta served as the discriminant factors.

The lower Langhian (lower Badenian) deposits of NN5 Zone outcropped in the Kosihovce, Príbelce, Stredné Plachtince, Horné Strháre and Trenč sections are estimated to be 14.9-14.4 Ma old.

The upper Langhian (lower Badenian) sediments from the Hámor section yield assemblages where $O$. suturalis and $T$. bisphericus are present and $H$. waltrans and $H$. ampliaperta are absent and points to an age of 14.4 Ma or younger (NN5b-5c Zone).

The described lithofacies reveal several distinct depositional environments. The older Burdigalian shelf break slope sediments, controlled by gravity deposition are toward overlying strata bounded by an unconformity. The lower Langhian shelf deposition was dominated by tide and wave processes and later passed into alluvial sediments on the margin 
of the Central Slovak Volcanic field. This might have been triggered due to pronounced volcanic activity, which shed larger volumes of material into the marine environment that partly overshadowed the climatic changes.

Change from warmer to cooler condition in the marine water mass has not been fully documented. The assemblages from the Karpatian sediments do not provide warm water conditions, however, warmer water was documented in the lower Langhian sediments. More visible changes are in the nutrient content, which changes from high nutrient during upper Burdigallian to low nutrient in the youngest studied sediments. Changes are probably a result of regional volcanic activity.

Landmass altitudinal zonation is shown in strikingly diversified pollen spectra composed of swamps, riparian forests, lowland aquatic and meadows growths, up to the mountain vegetation. Post-Burdigalian (Karpatian) cool- ing and aridification, followed by retreat of warmer and more humid conditions at the end of the Langhian (Badenian) is observed. Regional fluctuations in temperature and/or humidity can be considered partly as an impact of inicial MMCT in the epicontinental Central Paratethyan Sea domain.

\section{ACKNOWLEDGEMENTS}

This research was supported by the Slovak Research and Development Agency under the contracts APVV-16-0121, APVV-15-0575, APVV14-0118, APVV SK-AT-2017-0010, APVV 17-0555 and VEGA2/0169/19. Our gratitude goes to E.P. Radionova for diatom determinations. Part of the equipment used for this study was purchased from the Operational Programme Prague - Competitiveness (Project CZ.2.16/3.1.00/21516). This research was supported by the Center for Geosphere Dynamics (UNCE/SCI/006).

\section{REFERENCES}

Abdul Aziz, H., Di Stefano, A., Foresi, L.M., Hilgen, F.J., laccarino, S.M., Kuiper, K.F., Lirer, F., Salvatorini, G., and Turco, E. 2008. Integrated stratigraphy and ${ }^{40} \mathrm{Ar} /{ }^{39} \mathrm{Ar}$ chronology of early Middle Miocene sediments from DSDP Leg 42A, Site 372 (Western Mediterranean). Palaeogeography, Palaeoclimatology, Palaeoecology, 257:123-138. https://doi.org/10.1016/ j.palaeo.2007.09.013

Arkhangelsky, A.D. 1912. Upper Cretaceous deposits of east European Russia. Materialien zur Geologie Russlands, 25:1-631.

Backman, J. 1978. Late Miocene - Early Pliocene nannofossil biochronology and biogeography in the Vera Basin, SE Spain. Stockholm Contributions in Geology, 32:93-114.

Báldi, K. 2006. Paleoceanography and climate of the Badenian (Middle Miocene, 16.4-13.0 Ma) in the Central Paratethys based on foraminifera and stable isotope ( $\delta 180$ and $\delta 13 \mathrm{C}$ ) evidence. International Journal of Earth Science (Geologische Rundschau), 95:119-142. https://doi.org/10.1007/s00531-005-0019-9

Báldi, T. 1980. The early history of the Paratethys. Földtani Közlöny, 110:456-472. (In Hungarian with English summary)

Báldi-Beke, M. and Báldi, T. 1974. Nannoplankton and macrofauna of the type section at Novaj (Kiscellian- Egerian). Annales Universitatis Scientiarum Budapestinensis de Rolando Eotvos Nominatae, Sectio Geologica, 17:59-103.

Barron, J. and Baldauf, J.G. 2019. Cenozoic marine diatom biostratigraphy and applications to paleoclimatology and paleoceanography, p. 107-118. In: Blome, C. E., Whalen, P. M., and Reed, K. M. (eds.), Siliceous Microfossils. The Paleontological Society, Knoxville, Short Courses in Paleontology, 8. https://doi.org/10.1017/s2475263000001446

Bé, A.W.H. and Hutson, W. 1977. Ecology of planktonic foraminifera and biogeographic patterns of life and fossil assemblages in the Indian Ocean. Micropaleontology, 23:369-414. https:// doi.org/10.2307/1485406

Black, M. and Barnes, B. 1959. The structure of coccoliths from the English Chalk. Geological Magazine, 96:321-328.

Blow, W.H. 1956. Origin and evolution of the foraminiferal genus Orbulina d'Orbigny. Micropaleontology, 2(1):57-70. 
Blow, W.H. 1959. The classification and stratigraphical distribution of the Globigerinaceae. Palaeontology, 2:1-27.

Bolli, H.M. 1954. Note on Globigerina concinna Reuss 1850 (Point-a-Pierre, Trinidad). Contributions from the Cushman Foundation for Foraminiferal Research, 5(1):1-4.

Bolli, H.M., Loeblich, A.R., and Tappan, H. 1957. Planktonic foraminiferal families Hantkeninidae, Orbulinidae, Globorotaliidae and Globotruncanidae. Bulletin - United States National Museum, 215:3-50.

Borum, J., Sand-Jensen, K., Binzer, T., Pedersen, O., and Greve, T.M. 2006. Oxygen movement in seagrasses, p. 255-270. In Larkum, A.W.D., Orth, R.J., and Duarte, C.M. (eds.), Seagrasses: Biology, Ecology and Conservation. Springer, Dordrecht. https://doi.org/ 10.1007/978-1-4020-2983-7_10

Boltovskoy, E. and Wright, R. 1976. Recent Foraminifera. W. Junk, The Haugue. https://doi.org/ 10.1007/978-94-017-2860-7

Bown, P.R. 2005. Palaeogene calcareous nannofossils from the Kilwa and Lindi areas of coastal Tanzania (Tanzania Drilling Project 2003-4). Journal of Nannoplankton Research, 27(1):2195.

Brady, H.B. 1879. Notes on some of the reticularian Rhizopoda of the "Challenger" Expedition. Part I. On new or little known arenaceous types. Quarterly Journal of Microscopical Sciences, 19:20-67.

Brady, H.B. 1881. Notes on some of the Reticularian Rhizopoda of the "Challenger" Expedition. Part III. Quarterly Journal of Microscopical Science, 21(81):31-71.

Brady, H.B. 1882. Report on the foraminifera. In Tizard, S. and Murray, J. (eds.), Exploration of the Faräo Channel during the summer of 1880, in Her Majesty's hired ship "Knight Errant". Proceedings of the Royal Society of Edinburgh, 11:715.

Bramlette, M.N. and Martini, E. 1964. The great change in calcareous nannoplankton fossils between the Maestrichtian and Danian. Micropaleontology, 10(3):291-322.

Bramlette, M.N. and Riedel, W.R. 1954. Stratigraphic value of discoasters and some other microfossils related to recent coccolithophores. Journal of Paleontology, 28:385-403.

Bramlette, M.N. and Sullivan, F.R. 1961. Coccolithophorids and related nannoplankton of the Early Tertiary in California. Micropaleontology, 7(2):129-188.

Bramlette, M.N. and Wilcoxon, J.A. 1967. Middle Tertiary calcareous nannoplankton of the Cipero section, Trinidad, W.I. Tulane Studies in Geology and Paleontology, 5:93-131.

Brönnimann, P. 1951. The genus Orbulina d'Orbigny in the Oligo-Miocene of Trinidad, B.W.I. Contributions from the Cushman Foundation for Foraminiferal Research, 2(4):132-138.

Brönnimann, P. and Stradner, H. 1960. Die Foraminiferenund Discoasteriden-zonen von Kuba und ihre interkontinentale Korrelation. Erdoel-Zeitschrift, 76(10):364-369.

Brzobohatý, R., Cicha, I., Kováč, M., and Rogl, F. (eds.) 2003. The Karpatian - A Lower Miocene Stage of the Central Paratethys. Masaryk University, Brno.

Bukry, D. 1971a. Coccolith stratigraphy, Leg 7 DSDP. Initial Reports of the Deep Sea Drilling Project, 7:1513-1518.

Bukry, D. 1971b. Cenozoic calcareous nannofossils from the Pacific Ocean. San Diego Society of Natural History Transactions, 16:303-327.

Bukry, D. 1973. Coccolith stratigraphy, eastern equatorial Pacific, Leg 16, Deep Sea Drilling Project. Initial Reports of the Deep Sea Drilling Project, 16:653-711.

Cachão, M. and Moita, T.M. 2000. Coccolithus pelagicus, a productivity proxy related to moderate fronts off Western Iberia. Marine Micropaleontology, 39(1):131-155. https://doi.org/ 10.1016/s0377-8398(00)00018-9

Čechovič, V. and Seneš, J. 1950. Tortonian of the Modrý Kameň area. Geologický Sborník, Slovenská Akadémia Vied a Umení, 1(2-4):130-166. (In Slovak with Russian and French summary)

Cermeño, P., Falkowski, P.G., Romero, O.E., Schaller, M.F., and Vallina, S.M. 2015. Continental erosion and the Cenozoic rise of marine diatoms. Proceedings of the National Academy of Sciences of the United States of America, 112(14):4239-4244. https://doi.org/10.1073/ pnas.1412883112

Cicha, I., Čtyroká, J., Jiříček, R., and Zapletalová, I. 1975. Principal biozones of the Late Tertiary in the East Alps and West Carpathians, p. 19-34. In Cicha, I. (ed.), Biozonal division of the Upper Tertiary basins of the Eastern Alps and West Carpathians. IUGS Proceedings of the VI Congress Bratislava, Geological Survey, Prague. 
Cicha, I., Rögl, F., and Čtyroká, J. 2003. Central Paratethys Karpatian Foraminifera, p. 169-187. In Brzobohatý, R., Cicha, I., Kováč, M. and Rögl, F. (eds.), The Karpatian - A Lower Miocene Stage of the Central Paratethys. Masaryk University, Brno.

Cicha, I., Rögl, F., Rupp, Ch., and Čtyroká, J. (eds.) 1998. Oligocene - Miocene foraminifera of the Central Paratethys. Abhandlungen der Senckenbergischen Naturforschenden Gesellschaft, 549.

Csontos, L., Nagymarosy, A., Horváth, F., and Kováč, M. 1992. Tertiary evolution of the IntraCarpathian area: a model. Tectonophysics, 208:221-241. https://doi.org/10.1016/b978-0444-89912-5.50017-x

Cushman, J.A. 1926. Foraminifera of the typical Monterey of California. Contributions from the Cushman Laboratory for Foraminiferal Research, 2:53-69.

Cushman, J.A. 1930. The Foraminifera of the Choctawhatchee Formation of Florida. Florida State Geological Survey, Bulletin, 4:1-89.

Cushman, J.A. 1936. Some new species of Elphidium and related genera. Contributions from the Cushman Laboratory for Foraminiferal Research, 12(4):78-89.

Cushman, J.A. and Jarvis, P.W. 1936. Three new Foraminifera from the Miocene, Bowden Marl, of Jamaica. Contributions from the Cushman Laboratory for Foraminiferal Research, 12(1):35.

Cushman, J.A. and Ponton, J.M. 1932. An Eocene foraminiferal fauna of Wilcox age from Alabama. Contributions from the Cushman Laboratory for Foraminiferal Research, 8(3):5172.

Cžjžek, J. 1848. Beitrag zur Kenntniss der fossilen Foraminiferen des Wiener Beckens. Haidinger's Natur-wissenschaftliche Abhandlungen, 2:137-150.

Deflandre, G. 1952. Classe des Coccolithophoridés. (Coccolithophoridae. Lohmann, 1902), 439470. In Grassé, P.P. (ed.), Traite de Zoologie. Masson, Paris.

Deflandre in Piveteau, J. 1952. Traité de Paléontologie. p. 107-115. In Grassé, P.P. (ed.), Traité de zoologie. Anatomie, systématique, biologie, 1, part 1, Phylogenie. Protozoaires: généralités. Flagellés. Masson and Cie, Paris.

Deflandre, G. 1953. Hétérogénéité intrinsèque et pluralité des éleménts dans les coccolithes actuels et fossiles. Comptes Rendus Hebdomadaires des Séances de l'Académie des Sciences, Paris, 237:1785-1787.

Deflandre, G. and Fert, C. 1954. Observations sur les coccolithophoridés actuels et fossiles en microscopie ordinaire et électronique. Annales de Paléontologie, 40:115-176.

de Montfort, D. 1808. Conchyliologie Systematique el Classification Methodique des Coquilles (Tome Premier). F. Schoell, Paris.

Deshayes, G.P. 1830-1832. Encyclopédie méthodique ou par ordre de matières. Histoire Naturelle des Vers et Mollusques, 2(1):i-vi, 1-256 [1830]; 2(2):1-144 [1830], 145-594 [1832], 3:595-1152 [1832].

d'Orbigny, A.D. 1826. Tableau méthodique de la classe des Céphalopodes. Annales des Sciences Naturelles, 7:96-169, 245-314.

d'Orbigny, A.D. 1839. Foraminifères, In de la Sagra R., Histoire physique, politique et naturelle de l'ile de Cuba. A. Bertrand, Paris. p. 148. https://doi.org/10.5962/bhl.title.51128

d'Orbigny, A.D. 1846. Die fossilen Foraminiferen des tertiären Beckens von Wien. Foraminifères fossiles du bassin tertiaire de Vienne. Gide et Comp Libraries - editeurs, Paris.

d'Orbigny, A.D. 1850-1852. Prodrome de paléontologie stratigraphique universelle des animaux mollusques et rayonnés faisant suite au cours élémentaire de paléontologie et de géologie stratigraphiques. Masson, Paris, 1 [1850 ("1849")], 2 [1850], 3 [1852]. https://doi.org/ 10.5962/bhl.title.45605

Di Stefano, A., Foresi, L.M., Lirer, F., laccarino, S.M., Turco, E., Amore, F.O., Mazzei, R., Morabito, S., Salvatorini, G., and Abdul Aziz, H. 2008. Calcareous plankton high resolution bio-magnetostratigraphy for the Langhian of the Mediterranean area. Rivista Italiana di Paleontologia e Stratigrafia, 114(1):51-76. https://doi.org/10.13130/2039-4942/6369

Egger, J.G. 1893. Foraminiferen aus Meeresgrundproben, gelothet von 1874 bis 1876 von S.M. Sch. "Gazelle". Abhandlungen der Mathematisch-Physikalischen Classe der Königlich Bayerischen Akademie der Wissenschaften, 2(18) [1895]:193-458.

Ehrenberg, C.G. 1861. Über die Tiefgrunde-Verhältnisse des Oceans am Eingange der Davisstrafse und bei Island. Monatsbericht der Königlichen Akademie der Wissenschaften zu Berlin, 1861:275-315. 
Flores, J.-A., Sierro, F.J., Franés, G., Vázquez, A., and Zamarreno, I. 1997. The last 100,000 years in the western Mediterranean: sea surface water and frontal dynamics as revealed by coccolithophores. Marine Micropaleontology, 29:351-366. https://doi.org/10.1016/s03778398(96)00029-1

Fordinál, K., Král', J., Harčová, E., Čech, P., Zieliński, G., and Nagy, A. 2014. ${ }^{87} \mathrm{Sr} /{ }^{86} \mathrm{Sr}$, $\delta^{13} \mathrm{C}$ and $\delta^{18} \mathrm{O}$ in mollusc fossil shells from marine, brackish and freshwater environments from the Western Carpathians Tertiary sequences. Mineralia Slovaca, 46(1-2):23-44. (In Slovak with English summary)

Gardet, M. 1955. Contribution à l'étude des coccolithes des terrains néogènes de l'Algérie. Publications du Service de la Carte Géologique de l'Algérie (Nouvelle Série), 5:477-550.

Gartner, S. 1967. Calcareous nannofossils from Neogene of Trinidad, Jamaica, and Gulf of Mexico. Paleontological Contributions, University of Kansas, 29:1-7.

Gartner, S. 1969. Correlation of Neogene planktonic foraminifera and calcareous nannofossil zones. Transactions of the Gulf Coast Association of Geological Societies, 19:585-599.

Gartner, S. 1992. Miocene nannofossil chronology in the North Atlantic, DSDP Site 608. Marine Micropaleontology, 18:307-331.

Gartner, S. and Smith, L.A. 1967. Coccoliths and related calcareous nannofossils from the Yazoo Formation (Jackson, Late Eocene) of Louisiana. Paleontological Contributions, University of Kansas, 20:1-7.

Górka, H. 1957. Les Coccolithophoridés du Maestrichtien supérieur de Pologne. Acta Palaeontologica Polonica, 2:239-284.

Gradstein, F.M., Ogg, J.G., and Hilgen, F.J. 2012. On the Geologic Time Scale. Newsletters on Stratigraphy, 45(2):171-188.

Grün, W. and Allemann, F. 1975. The Lower Cretaceous of Caravaca (Spain): Berriasian calcareous nannoplankton of the Miravetes Section (Subbetic Zone, Prov. of Murcia). Eclogae Geologicae Helvetiae, 68:147-211.

Grunert, P., Soliman, A., Harzhauser, M., Müllegger, S., Piller, W.E., Roetzel, R., and Rögl, F. 2010. Upwelling conditions in the Early Miocene Central Paratethys Sea. Geologica Carpathica, 61(2):129-145.

Guérin-Méneville, F.E. 1829-1844. Iconographie du Règne Animal de G. Cuvier, ou représentation d'après nature de l'une des espèces les plus remarquables, et souvent non encore figurées, de chaque genre d'animaux, avec un texte descriptif mis au courant de la science. Ouvrage pouvant servir d'atlas à tous les traités de Zoologie (Crustacés). J.B. Baillière, Paris and London.

Hammer, Ø., Harper, D.A.T., and Ryan, P.D. 2001. PAST: paleontological statistics software package for education and data analysis. Palaeontologia Electronica, 4.1.4:1-9. http:// palaeo-electronica.org/2001_1/past/issue1_01.htm

Handy, M.R., Schmid, S.M., Bousquet, R., Kissling, E., and Bernoulli, D. 2010. Reconciling platetectonic reconstructions of Alpine Tethys with the geological-geophysical record of spreading and subduction in the Alps. Earth Science Reviews, 102:121-158. https://doi.org/10.1016/ j.earscirev.2010.06.002

Handy, M.R., Ustaszewski, K., and Kissling, E. 2015. Reconstructing the Alps-CarpathiansDinarides as a key to understanding switches in subduction polarity, slab gaps and surface motion. International Journal of Earth Sciences, 104:1-26. https://doi.org/10.1007/s00531014-1060-3

Hano, V. 1950. Tortonian fauna from the Kosihovce (southern Slovakia). Geologický Sbornik, 1(1):70-73. (In Slovak)

Haq, B.U. 1966. Electron microscope studies on some upper Eocene calcareous nannoplankton from Syria. Stockholm Contributions in Geology, 15:23-37.

Haq, B.U. 1968. Studies on upper Eocene calcareous nannoplankton from NW Germany. Stockholm Contributions in Geology, 18:13-74.

Haq, B.U. 1971. Paleogene calcareous nannoflora. Parts I-IV. Stockholm Contributions in Geology, 25:1-158.

Harzhauser, M., Mandic, O., and Zuschin, M. 2003. Changes in Paratethyan marine molluscs at the early/middle Miocene transition - diversity, paleogeography and paleoclimate. Acta Geologica Polonica, 53:323-339. 
Harzhauser, M. and Piller, W.E. 2007. Benchmark data of a changing sea - palaeogeography, palaeobiogeography and events in the Central Paratethys during the Miocene.

Palaeogeography, Palaeoclimatology, Palaeoecology, 253:8-31. https://doi.org/10.1016/ j.palaeo.2007.03.031

Harzhauser, M., Piller, W.E., and Steininger, F.F. 2002. Circum-Mediterranean Oligo/Miocene biogeographic evolution - the gastropods' point of view. Palaeogeography, Palaeoclimatology, Palaeoecology, 183:103-133. https://doi.org/10.1016/s00310182(01)00464-3

Hay, W.W. and Mohler, H.P. 1967. Calcareous nannoplankton from Early Tertiary rocks at Point Labau, France and Paleocene-Early Eocene correlations. Journal of Paleontology, 41(6):1505-1541.

Hay, W.W., Mohler, H.P., Roth, P.H., Schmidt, R.R., and Boudreaux, J.E. 1967. Calcareous nannoplankton zonation of the Cenozoic of the Gulf Coast and Caribbean-Antillean area, and transoceanic correlation. Transactions of the Gulf Coast Association of Geological Societies, $17: 428-480$.

Hay, W.W., Mohler, H.P., and Wade, M.E. 1966. Calcareous nannofossils from Nal'chik (northwest Caucasus). Eclogae Geologicae Helvetiae, 59:379-399.

Hohenegger, J. 2005. Estimation of environmental paleogradient values based on presence/ absence data: a case study using benthic foraminifera for paleodepth estimation. Palaeogeography, Palaeoclimatology, Palaeoecology, 217:115-130. https://doi.org/10.1016/ j.palaeo.2004.11.020

Hohenegger, J., Ćorić, S., Khatun, M., Pervesler, P., Rögl, F., Rupp, C., Selge, A., Uchman, A., and Wagreich, M. 2009. Cyclostratigraphic dating in the Lower Badenian (Middle Miocene) of the Vienna Basin (Austria): the Baden-Sooss core. International Journal of Earth Sciences, 98:915-930. https://doi.org/10.1007/s00531-007-0287-7

Hohenegger, J., Ćorić, S., and Wagreich, M. 2014. Timing of the middle Miocene Badenian Stage of the central Paratethys. Geologica Carpathica, 65(1):55-66.

Holbourn, A., Kuhnt, W., Clemens, S., Prell, W., and Andersen, N. 2013. Middle to late Miocene stepwise climate cooling: Evidence from a high-resolution deep water isotope curve spanning 8 million years. Paleoceanography, 28:688-699. https://doi.org/10.1002/ 2013pa002538

Holbourn, A., Kuhnt, W., Schulz, M., and Erlenkeuser, H. 2005. Impacts of orbital forcing and atmospheric carbon dioxide on Miocene ice-sheet expansion. Nature, 438:483-487. https:// doi.org/10.1038/nature04123

Holcová, K. 1996. Determination of transport of foraminiferal tests in the fossil record (South Slovakian Basin, Middle Miocene). Neues Jahrbuch für Geologie und Paläontologie Monatshefte, H4:193-217. https://doi.org/10.1127/njgpm/1996/1996/193

Holcová, K. 2001. Foraminifera and calcareous nannoplankton from the "Rzehakia (Oncophora) Beds" in the Central Paratethys. Neues Jahrbuch für Geologie und Paläontologie Abhandlungen, 220(2):189-223. https://doi.org/10.1127/njgpa/220/2001/189

Holcová, K. 2013. Morphological variability of the Paratethyan Oligocene-Miocene small reticulofenestrid coccolites and its paleoecological and paleogeographical implications. Acta Palaeontologica Polonica, 58(3):651-668. https://doi.org/10.4202/app.2009.0006

Holcová, K. and Demény, A. 2012. The oxygen and carbon isotopic composition of Langhian foraminiferal tests as a paleoecological proxy in a marginal part of the Carpathian Foredeep (Czech Republic). Geologica Carpathica, 63(2):121-137.

Holcová, K. and Zágoršek, K. 2008. Bryozoa, foraminifera and calcareous nannoplankton as environmental proxies of the "bryozoan event" in the Middle Miocene of the Central Paratethys (Czech Republic). Palaeogeography, Palaeoclimatology, Palaeoecology, 267:216-234. https://doi.org/10.1016/j.palaeo.2008.06.019

Holcová, K., Brzobohatý, R., Kopecká, J., and Nehyba S. 2015a. Reconstruction of the unusual Middle Miocene (Badenian) palaeoenvironment of the Carpathian Foredeep (Lomnice/Tišnov denudational relict, Czech Republic). Geological Quarterly, 59(4):654-678. https://doi.org/ 10.7306/gq.1249

Holcová, K., Hrabovský, J., Nehyba, S., Hladilová, Š., Doláková, N., and Demény, A. 2015b. The Langhian (Middle Badenian) carbonate production event in the Moravian part of the Carpathian Foredeep (Central Paratethys): a multiproxy record. Facies, 61:1-26. https:// doi.org/10.1007/s10347-014-0419-z 
Holcová, K., Doláková, N., Nehyba, S., and Vacek, F. 2018. Timing of Langhian bioevents in the Carpathian Foredeep and northern Pannonian Basin in relation to oceanographic, tectonic and climatic processes. Geological Quarterly, 62(1):3-17. https://doi.org/10.7306/gq.1399

Hosius, A. 1895. Beitrag zur Kenntnis der Foraminiferenfauna des Ober-Oligozäns von Doberg bei Bünde, II. Teil. Naturwissenschaftlichen Vereins zu Osnabrück, Jahresberichte, 10:1-167.

Hüsing, S.K., Cascella, A., Hilgen, F.J., Krijgsman, W., Kuiper, K.F., Turco, E., and Wilson, D. 2010. Astrochronology of the Mediterranean Langhian between 15.29 and 14.17 Ma. Earth and Planetary Science Letters, 290:254-269. https://doi.org/10.1016/j.epsl.2009.12.002

Hyžný, M., Hudáčková, N., and Szalma, Š. 2015. Taphonomy and differential diversity of the Middle Miocene decapod crustaceans from the Plášt'ovce Member of the Sebechleby Formation (Novohrad-Nógrad Basin, Slovakia), with remarks on palaeobiogeography. Acta Geologica Slovaca, 7(2):139-154.

laccarino, S.M., Di Stefano, A., Foresi, L.M., Turco, E., Baldassini, N., Cascella, A., Da Prato, S., Ferraro, L., Gennari, R., Hilgen, F.J., Lirer, F., Maniscalco, R., Mazzei, R., Riforgiato, F., Russo, B., Sagnotti, L., Salvatorini, G., Speranza, F., and Verducci, M. 2011. High-resolution integrated stratigraphy of the upper Burdigalian-lower Langhian in the Mediterranean: the Langhian historical stratotype and new candidate sections for defining its GSSP. Stratigraphy, 8(2-3):199-215.

Jenkins, D.G. 1960. Planktonic foraminifers from the Lakes Entrance oil shaft, Victoria, Australia. Micropaleontology, 6(4):345-371.

Jenkins, D.G. 1966. Planktonic foraminiferal zones and new taxa from the Danian to lower Miocene of New Zealand. New Zealand Journal of Geology and Geophysics, 8:1088-1126.

Káčer, Š., Antalík, M., Lexa, J., Zvara, I., Fritzman, R., Vlachovič, J., Bystrická, G., Bordianska, M., Madarás, J., Nagy, A., Maglay, J., Ivanička, J., Gross, P., Rakús, M., Vozárová, A., Buček, S., Boorová, D., Šimon, L., Mello, J., Polák, M., Bezák, V., Hók, J., Teták, F., Konečný, V., Kučera, M., Žec, B., Elečko, M., Hraško, L'., Kováčik, M., and Pristaš, J. 2005. Digital geological map of Slovakia. 1:50 000. MŽPSR, GÚDŠ, Bratislava. (In Slovak)

Kaiho, K. 1994. Benthic foraminiferal dissolved-oxygen index and dissolved-oxygen levels in the modern ocean. Geology, 22:719-722. https://doi.org/10.1130/00917613(1994)022<0719:bfdoia>2.3.co;2

Kameo, K. 2002. Late Pliocene Caribbean surface water dynamics and climatic changes based on calcareous nannofossil records. Palaeogeography, Palaeoclimatology, Palaeoecology, 179:211-226. https://doi.org/10.1016/s0031-0182(01)00432-1

Kamptner, E. 1927. Beitrag zur Kenntnis adriatischer Coccolithophoriden. Archiv für Protistenkunde, 58:173-184.

Kamptner, E. 1948. Coccolithen aus dem Torton des Inneralpinen Wiener Beckens. Anzeiger. Österreichische Akademie der Wissenschaften, Mathematische-Naturwissenschafliche Klasse, Wien, 157:1-16.

Kamptner, E. 1954. Untersuchungen über den Feinbau der Coccolithen. Anzeiger. Österreichische Akademie der Wissenschaften. Mathematische-Naturwissenschafliche Klasse, Wien, 87:152-158.

Kamptner, E. 1955. Fossile Coccolithineen-Skelettreste aus Insulinde. Eine mikropaläontologische Untersuchung. Koninklijke Nederlandse Akademie van Wetenschappen, Afdeling Natuurkunde Verhandelingen, series 2(50):1-105.

Kamptner, E. 1963. Coccolithineen-Skelettreste aus Tiefseeablagerungen des Pazifischen Ozeans. Annalen des Naturhistorischen Museums in Wien, 66:139-204.

Keller, G. 1985. Depth stratification of planktonic foraminifers in the Miocene ocean. Geological Society of America, Memoir, 163:177-195. https://doi.org/10.1130/mem163-p177

Kennett, J. and Srinivasan, M.S. 1983. Neogene Planktonic Foraminifera - A Phylogenetic Atlas. University of Rhode Island, Hutchinson Ross Publishing Company, Stroudsburg, Pennsylvania.

Kern, A., Harzhauser, M., Mandic, O., Roetzel, R., Ćorić, S., Bruch, A., and Zuschin, M. 2011. Millennial-scale vegetation dynamics in an estuary at the onset of the Miocene climate optimum. Palaeogeography, Palaeoclimatology, Palaeoecology, 304:247-261. https://doi.org/ 10.1016/j.palaeo.2010.07.014

Konečný, V., Pristaš, J., and Vass, D. 1983. Explanations to the geological map of the Ipel'ská kotlina lowland and southern part of Krupinská planina moutains in scale 1:50 000. GÚDŠ, Bratislava. (In Slovak) 
Kováč, M. 2000. Geodynamic, palaeogeographic and structural development of the CarpathoPannonian region during the Miocene: new view on the Neogene basins of Slovakia. VEDA, SAV, Bratislava. (In Slovak)

Kováč, M., Nagymarosy, A., Oszczypko, N., Csontos, L., Slaczka, A., Mãrunteanu, M., Matenco, L., and Márton, E. 1998. Palinspastic reconstruction of the Carpathian - Pannonian region during the Miocene, p. 189-217. In Rakús, M. (ed.), Geodynamic Development of the Western Carpathians. Geological Survey of Slovak Republic, Bratislava.

Kováč, M., Baráth, I., Harzhauser, M., Hlavatý, I., and Hudáčková, N. 2004. Miocene depositional systems and sequence stratigraphy of the Vienna Basin. Courier Forschungsinstitut Senckenberg, 246:187-212.

Kováč, M., Andreyeva-Grigorovich, A., Bajraktarević, Z., Brzobohatý, R., Filipescu, S., Fodor, L., Harzhauser, M., Nagymarosy, A., Oszczypko, N., Pavelić, D., Rögl, F., Saftić, B., Sliva, L'., and Studencka, B. 2007. Badenian evolution of the Central Paratethys Sea: paleogeography, climate and eustatic sea-level changes. Geologica Carpathica, 58(6):579-606.

Kováč, M., Plašienka, D., Soták, J., Vojtko, R., Oszczypko, N., Less, Gy., Ćosović, V., Fügenschuh, B., and Králiková S. 2016. Paleogene palaeogeography and basin evolution of the Western Carpathians, Northern Pannonian domain and adjoining areas. Global and Planetary Change, 140:9-27. https://doi.org/10.1016/j.gloplacha.2016.03.007

Kováč, M., Márton, E., Oszczypko, N., Vojtko, R., Hók, J., Králiková, S., Plašienka, D., Klučiar, T., Hudáčková, N., and Oszczypko-Clowes, M. 2017. Neogene palaeogeography and basin evolution of the Western Carpathians, Northern Pannonian domain and adjoining areas. Global and Planetary Change, 155:133-154. https://doi.org/10.1016/j.gloplacha.2017.07.004

Kováč, M., Halásová, E., Hudáčková, N., Holcová, K., Hyžný, M., Jamrich, M., and Ruman, A. 2018a. Towards better correlation of the Central Paratethys regional time scale with the standard geological time scale of the Miocene Epoch. Geologica Carpathica, 69(3):283-300. https://doi.org/10.1515/geoca-2018-0017

Kováč, M., Rybár, S., Halásová, E., Hudáčková, N., Šarinová, K., Šujan, M., Baranyi, V., Kováčová, M., Ruman, A., Klučiar, T., and Zlinská, A. 2018b. Changes in Cenozoic depositional environment and sediment provenance in the Danube Basin. Basin Research, 30:97-131. https://doi.org/10.1111/bre.12244

Kováčová, M., Doláková, N., and Kováč, M. 2011. Miocene vegetation pattern and climate change in the northwestern Central Paratethys domain (Czech and Slovak Republic). Geologica Carpathica, 62(3):251-266.

Kretschmer, K., Jonkers, L., Kučera, M., and Schulz, M. 2018. Modeling deasonal and vertical habitats of planktonic foraminifera on a global scale. Biogeosciences, 15:4405-4429. https:// doi.org/10.5194/bg-15-4405-2018

Kroh, A. 2007. Hemipatagus, a misinterpreted loveniid (Echinodermata: Echinoidea). Journal of Systematic Palaeontology, 5:163-192. https://doi.org/10.1017/s1477201906002021

LeRoy, L.W. 1939. Some small foraminifers, ostracoda and otoliths from the Neogene ("Miocene") of the Rokan-Tapanoeli area Central Sumatra. Natuurkunde Tijdschrift voor Nederlandsch-Indië, 99:214-296.

Less, Gy., Frijia, G., Filipescu, S., Holcová, K., Mandic, O., and Sztanó, O. 2015. New Sr-isotope stratigraphy (SIS) age-data from the Central Paratethys, p.223. In Gülli, E. and Piller, W.E. (eds.), 2nd International Congress on Stratigraphy. Abstracts. Berichte des Institutes für Erdwissenschaften der Karl-Franzens Universität Graz.

Levin, H.L. 1965. Coccolithophoridae and related microfossils from the Yazoo Formation (Eocene) of Mississippi. Journal of Paleontology, 39:2:265-272.

Levin, H.L. and Joerger, A.P. 1967. Calcareous nannoplankton from the Tertiary of Alabama. Micropaleontology, 13:163-182.

Linnaeus, C. 1758. Systema Naturae. Vol. 1. 10th ed. Holmiae L. Salvii, Stockholm.

Loeblich, A.R. and Tappan, H. 1978. The coccolithophorid genus Calcidiscus Kamptner and its synonyms. Journal of Paleontology, 52:1390-1392.

Loeblich, A.R. and Tappan, H. 1992. Present status of foraminiferal classification, p. 93-102. In Takayanagi, Y. and Saito, T. (eds.), Studies in Benthic Foraminifera. Proceedings of the Fourth Symposium on Benthic Foraminifera, Sendai, Tokai University Press.

Lohmann, H. 1902. Die Coccolithophoridae, eine Monographie der Coccolithen bildenden Flagellaten, zugleich ein Beitrag zur Kenntnis des Mittelmeerauftriebs. Archiv für Protistenkunde, 1:89-165. 
Luczkowska, E. 1955. Tortonian Foraminifera from the Chodenice and Grabowiec beds in the Bochnia area. Annales Societatis Geologorum Poloniae, Krakow, 23(1953):77-156. (In Polish with Russian abstract)

Macfayden, W.A., 1930. Miocene foraminifera from the clysmic area of Egypt and Sinai, with an account of the stratigraphy and a correlation of the local Miocene succession. Surveys of Egyptian Geological Survey, 40:1-149.

Mandic, O., De Leeuw, A., Vuković, B., Krijgsman, W., Harzhauser, M., and Kuiper, K.F. 2011. Palaeoenvironmental evolution of Lake Gacko (Southern Bosnia and Herzegovina): Impact of the Middle Miocene Climatic Optimum on the Dinaride Lake System. Palaeogeography, Palaeoclimatology, Palaeoecology, 299:475-492. https://doi.org/10.1016/ j.palaeo.2010.11.024

Martini, E. 1965. Mid-Tertiary calcareous nannoplankton from Pacific deep-sea cores. Colston Papers, 17:393-411.

Martini, E. and Bramlette, M.N. 1963. Calcareous nannoplankton from the experimental Mohole drilling. Journal of Paleontology, 37:845-855.

Martini, E. and Ritzkowski, S. 1968. Was ist das 'Unter-Oligozän'? Eine Analyse der Beyrich'schen und $v$ Koenen'schen Fassung der Stufe mit Hilfe des fossilen Nannoplanktons. Nachrichten der Akademie der Wissenschaften in Göttingen. II. Mathematisch-Physikalische Klasse, 13:231-250.

Márton, E. 2006. Paleomagnetic constraints for the reconstruction of the geodynamic evolution of the Middle Miocene-Pleistocene, p. 55-64. In Pinter, N., Grenerczy, G., Weber, J., Stein, S., and Medak, D. (eds.), The Adria Microplate: GPS Geodesy, Tectonics and Hazards. Kluwer Academic, Amsterdam. https://doi.org/10.1007/1-4020-4235-3_06

Matenco, L., Bertotti, G., Dinu, C., and Cloetingh, S. 1997. Tertiary tectonic evolution of the external South Carpathians and the adjacent Moesian platform (Romania). Tectonics, 16(6):896-911. https://doi.org/10.1029/97tc01238

McCulloch, I. 1977. Qualitative Observations on Recent Foraminiferal Tests with Emphasis on the Eastern Pacific. Parts I-III. University of Southern California, Los Angeles.

Meilijson, A., Ashckenazi-Polivoda, S., Illner, P., Alsenz, H., Speijer, R.P., Almogi-Labin, A., Feinstein, S., Püttmann, W., and Abramovich, S. 2016. Evidence for specific adaptations of fossil benthic foraminifera to anoxic-dysoxic environments. Paleobiology, 42(1):77-97. https:/ /doi.org/10.1017/pab.2015.31

Melioris, L. and Vass, D. 1982. Hydorogeological and geological settings of the Levice "žriedelná" line. Západné Karpaty, Séria hydrogeológia a inžinierska geológia, 4:7-56.

Miall, A.D. 2006. The Geology of Fluvial Deposits. Springer, New York. https://doi.org/10.1007/ 978-3-662-03237-4

Miller, P.L. 1981. Tertiary calcareous nannoplankton and benthic foraminifera biostratigraphy of the Point Arena area, California. Micropaleontology, 27:419-443.

Molčíková, V. 1964. Contribution on ecology of lower Badenian microfauna of the Danube Basin. Práce Výzkuního Ústavu československých naftových Dolů, Praha, 21(98)E:111-126. (In Czech with English and Russian summary)

Moshkovitz, S. and Ehrlich, A. 1980. Distribution of the calcareous nannofossils in the Neogene sequence of the Jaffa-1 Borehole, Central Coastal Plain, Israel. Geological Survey of Israel Report, PD1(80):1-25.

Müller, C. 1970. Nannoplankton aus dem Mittel-Oligozän von Norddeutschland und Belgien. Neues Jahrbuch für Geologie und Paläontologie Abhandlungen, 135:82-101.

Müller, C. 1974. Nannoplankton aus dem Mittel-Miozän von Walbersdorf (Burgenland). Senckenbergiana Lethaea, 55:389-405.

Müller, C. 1981. Beschreibung neuer Helicosphaera-Arten aus dem Miozän und Revision biostratigraphischer Reichweiten einiger neogener Nannoplankton-Arten. Senckenbergiana Lethaea, 61:427-435.

Murray, G. and Blackman, V.H. 1898. On the nature of the coccospheres and rhabdospheres. Philosophical Transactions of the Royal Society of London (B), 190(1):427-441.

Murray, J.W. 1973. Distribution and Ecology of Benthic Foraminiferids. Heinemann Educational Books, London.

Murray, J.W. 2006. Ecology and Applications of Benthic Foraminifera. Cambridge University Press, Cambridge.

Nalepka, D. and Walanus, A. 2003. Data processing in pollen analysis. Acta Paleobotánica, 43(1):125-134. 
Natland, M.L. 1938. New species of foraminifers from off the West Coast of North America and from the later Tertiary of the Los Angeles Basin. Bulletin of the Scripps Institution of Oceanography. Technical series. 4(5):137-164.

Neugeboren, L. 1850. Die vorweltlichen Squaliden-Zähne aus dem Grobkalke bei Portsesd am Altflusse unweit Talmatsch. Archiv des Vereins für Siebenbürgische Landeskunde, 4(2):1-44, pl. 1-2.

Okada, H. and Mclntyre, A. 1979. Seasonal distribution of modern coccolithophores in the western North Atlantic Ocean. Marine Biology, 54:319-328. https://doi.org/10.1007/ bf00395438

Oksanen, J., Guillaume Blanchet, F., Friendly, M., Kindt, R., Legendre, P., McGlinn, D., Minchin, P.R., O'Hara, R.B., Simpson, G.L., Solymos, P., Stevens, M.H.H., Szoecs, E., and Wagner, H. 2017. Vegan: community ecology package. $\mathrm{R}$ package version $2.4-4$. https://cran.rproject.org/package=vegan

Owen, G., Moretti, M., and Alfaro, P. 2011. Recognising triggers for soft-sediment deformation: Current understanding and future directions. Sedimentary Geology, 235:133-140. https:// doi.org/10.1016/j.sedgeo.2010.12.010

Ozdínová, S. and Soták, J. 2014. Oligocene-Early Miocene planktonic microbiostratigraphy and paleoenvironments of the South Slovakian Basin (Lučenec Depression). Geologica Carpathica, 65(6):451-470. https://doi.org/10.1515/geoca-2015-0005

Pallas, P.S. 1766. Elenchus zoophytorum sistens generum adumbrationes generaliores et specierum cognitarum succintas descriptiones, cum selectis auctorum synonymis. Fransiscum Varrentrapp, Hagae.

Papp, A. and Turnovsky, K. 1953. Die Entwicklung der Uvigerinen im Vindobon (Helvet und Torton) des Wiener Beckens. Jahrbuch der Geologischen Bundesanstalt, Wien, 96(1):117142.

Patruno, S. and Helland-Hansen, W. 2018. Clinoforms and clinoform systems: Review and dynamic classification scheme for shorelines, subaqueous deltas, shelf edges and continental margins. Earth-Science Reviews, 185:202-233. https://doi.org/10.1016/ j.earscirev.2018.05.016

Pearson, P.N. and Shackleton, N.J. 1995. Neogene multispecies planktonic foraminifer stable isotope record, Site 871, Limalok Guyot. Proceedings of the Ocean Drilling Program, Scientific Results, 144:21-59. https://doi.org/10.2973/odp.proc.sr.144.054.1995

Pécskay, Z., Lexa, J., Szakacs, A., Seghedi, I., Balogh, K., Konečný, V., Zelenka, T., Kovacs, M., Póka, T., Fulop, A., Márton, E., Panaiotu, C., and Cvetković, V. 2006. Geochronology of Neogene magmatism in the Carpathian arc and intra-Carpathian area. Geologica Carpathica, 57(6):511-530.

Perch-Nielsen, K. 1968. Der Feinbau und die Klassifikation der Coccolithen aus dem Maastrichtien von Danemark. Biologiske Skrifter. Kongelige Danske Videnskabernes Selskab, 16:1-96.

Perch-Nielsen, K. 1984. Validation of new combinations. INA Newsletter, 6(1):42-46.

Piller, W.E., Harzhauser, M., and Mandic O. 2007. Miocene Central Paratethys stratigraphy current status and future directions. Stratigraphy, 4(2-3):151-168.

Piller, W.E., Summesberger, H., Draxler, I., Harzhauser, M., and Mandic, O. 1997. Meso- to Cenozoic tropical/subtropical climates - Selected examples from the Northern Calcareous Alps and the Vienna Basin, p. 70-111. In Kollmann, H.A. and Hubmann, B., (eds.), Excursion Guides, 2nd European Paleontological Congress, Climates: Past, Present and Future.

Pivko, D., Hudáčková, N., Hrabovský, J., Sládek, I., and Ruman, A. 2017. Palaeoecology and sedimentology of the Miocene marine and terrestrial sediments in the "Medieval quarry" on the Devínska Kobyla hill (Vienna Basin). Geological Quarterly, 61(3):549-568. https://doi.org/ 10.7306/gq.1357

Planderová, E. 1990. Miocene Microflora of Slovak Central Paratethys and its Biostratigraphical Significance. Dionýz Štúr Institute of Geology, Bratislava.

Popescu, G. 1970. Planktonic foraminiferal zonation in the Dej tuff complex. Revue Roumaine de Geologie, Geophysique et Geographie, Serie de Geologie, 14:189-203.

Popov, S.V., Rögl, F., Rozanov, A.Y., Steininger, F.F., Shcherba, I.G., and Kováč, M. (eds.) 2004. Lithological-paleogeographic maps of Paratethys. 10 maps late Eocene to Pliocene. Courier Forschungsinstitut Senckenberg, 250:1-46. 
Pound, M.J., Haywood, A.M., Salzmann, U., and Riding, J.B. 2012. Global vegetation dynamics and latitudinal temperature gradients during the Mid to Late Miocene (15.97-5.33 Ma). EarthScience Reviews, 112(1-2):1-22. https://doi.org/10.1016/j.earscirev.2012.02.005

R Core Team, 2014, R. A language and environment for statistical computing. R Foundation for Statistical Computing, Vienna, Austria. http://www.R-project.org/

Reinhardt, P. 1964. Einige Kalkflagellaten-Gattungen (Coccolithophoriden, Coccolithineen) aus dem Mesozoikum Deutschlands. Monatsberichte der Deutschen Akademie der Wissenschaften zu Berlin, 6:749-759.

Reinhardt, P. 1965. Neue Familien für fossile Kalkflagellaten (Coccolithophoriden, Coccolithineen). Monatsberichte der Deutschen Akademie der Wissenschaften zu Berlin, 7:30-40.

Reinhardt, P. and Górka, H. 1967. Revision of some Upper Cretaceous coccoliths from Poland and Germany. Neues Jahrbuch für Geologie und Paläontologie Abhandlungen, 129:240-256.

Reuss, A.E. 1850. Neue Foraminiferen aus den Schichten des österreichischen Tertiärbeckens. Denkschriften der Kaiserlichen Akademie der Wissenschaften. 1:365-390.

Reuss, A.E. 1851. Ueber die fossilen Foraminiferen und Entomostraceen der Septarienthone der Umgegend von Berlin. Zeitschrift der Deutschen Geologischen Gesellschaft, 3(1):49-92.

Reuss, A.E. 1865. Zur Fauna des deutschen Oberoligocäns. Erste Abtheilung. Sitzungsberichte der mathematisch-naturwissenschaflichen Classe der kaiserlichen Akademie der Wissenschaften, 50(1)[1864]:435-482.

Reynolds, L. and Thunell, R. C. 1989. Seasonal succession of planktonic foraminifera: results from a four year time series sediment trap experiment in the northeast Pacific. Journal of Foraminiferal Research, 19(4):253-267. https://doi.org/10.2113/gsjfr.19.4.253

Romein, A.J.T. 1979. Lineages in Early Paleogene calcareous nannoplankton. Utrecht Micropaleontological Bulletin, 22:1-232.

Rossi, V.M., Perillo, M.M., Steel, R.J., and Olariu, C. 2017. Quantifying mixed-process variability in shallow-marine depositional systems: What are sedimentary structures really telling us? Journal of Sedimentary Research, 87(10):1060-1074. https://doi.org/10.2110/jsr.2017.49

Roth, P.H. 1970. Oligocene calcareous nannoplankton biostratigraphy. Eclogae Geologicae Helvetiae, 63:799-881.

Roth, P.H. and Thierstein, H.R. 1972. Calcareous nannoplankton: Leg 14 of the Deep Sea Drilling Project. Initial Reports of the Deep Sea Drilling Project, 12:546-559.

Rybár, S., Kováč, M., Šarinová, K., Halásová E., Hudáčková, N., Šujan, M., Kováčová, M., Ruman, A., and Klučiar, T. 2016. Neogene changes in paleeogeography, palaeoenvironment and the provenance of sediment in the Northern Danube Basin. Bulletin of Geosciences, 91(2):367-398. https://doi.org/10.3140/bull.geosci.1571

Rupp, Ch. and Hohenegger, J. 2008. Paleoecology of planktonic foraminifera from the BadenSooss section (Middle Miocene, Badenian, Vienna Basin, Austria). Geologica Carpathica, 59(5):425-445.

Rzehak, A. 1886. Die Foraminiferen Fauna der Neogenformation der Umgebung von MährOstrau. Verhandlungen des naturforschenden Vereines in Brünn, 24:77-126.

Sant, K., Palcu, D., Mandic, O., and Krijgsman, W. 2017. Changing seas in the Early-Middle Miocene of Central Europe: a Mediterranean approach to Paratethyan stratigraphy. Terra Nova, 29:273-281. https://doi.org/10.1111/ter.12273

Sant, K., Kuiper, K.F., Rybár, S., Grunert, P., Harzhauser, M., Mandic, O., Jamrich, M., Šarinová, K., Hudáčková, N., and Krijgsman, W. 2020: ${ }^{40} \mathrm{Ar} /{ }^{39} \mathrm{Ar}$ geochronology using high sensitivity mass spectrometry: Examples from middle Miocene horizons of the Central Paratethys. Geologica Carpathica, 71(2):166-82. https://doi.org/10.31577/GeolCarp.71.2.5

Scheiner, F., Holcová, K., Milovský, R., and Kuhnert, H. 2018. Temperature and isotopic composition of seawater in the epicontinental sea (Central Paratethys) during the Middle Miocene Climate Transition based on $\mathrm{Mg} / \mathrm{Ca}, \delta^{18} \mathrm{O}$ and $\delta^{13} \mathrm{C}$ from foraminiferal tests. Palaeogeography, Palaeoclimatology, Palaeoecology, 495:60-71. https://doi.org/10.1016/ j.palaeo.2017.12.027

Schiller, J. 1930. Coccolithineae, p. 89-267. In Rabenhorst, L. (ed.), Kryptogamen-Flora von Deutschland, Österreich und der Schweiz. Akademische Verlagsgesellschaft, Leipzig.

Schmid, S.M., Bernoulli, D., Fügenschuh, B., Matenco, L., Schefer, S., Schuster, R., Tischler, M., and Ustaszewski, K. 2008. The Alpine-Carpathian-Dinaridic orogenic system: correlation and evolution of tectonic units. Swiss Journal of Geosciences, 101(1):139-183. https://doi.org/ 10.1007/s00015-008-1247-3 
Seneš, J. 1949. Geological studies about south Slovakian Tertiary. Práce Štátneho geologického Ústavu, 23:1-76. (In Slovak with Russian and French summary)

Seneš, J. 1954. Note to the molluscan biocenoses from the littoral sediments. Geologický Sborník Slovenskej Akadémie Vied, 4(1953)(3-4):883-892. (In Slovak with German and Russian summary)

Sen Gupta, B.K., Smith, L.E., Machain-Castillo, M.L. 2009. Foraminifera of the Gulf of Mexico, p. 87-129. In Felder, D.L. and D.K. Camp (eds.), Gulf of Mexico-Origins, Waters, and Biota: Biodiversity. Texas A\&M Press, College Station, Texas.

Sgarrella, F. and Moncharmont-Zei, M. 1993. Benthic Foraminifera of the Gulf of Naples (Italy): systematics and autoecology, Modena. Bolletino della Societa Paleontologica Italiana, 32(2):145-264.

Shevenell, A., Kenneth, J.P., and Lea, D.W. 2008. Middle Miocene ice sheet dynamics, deep-sea temperatures, and carbon cycling: A Southern Ocean perspective. Geochemistry, Geophysics, Geosystems, 9(2):1-14. https://doi.org/10.1029/2007gc001736

Soron, A. 2011. Paleoenvironmental and stratigraphic investigations of the foraminiferal fauna from the Karpatian (Lower Miocene) Garáb Schlier Formation of the Mátraverebély-122 (Mv122) borehole (North Hungary). Central European Geology, 54(3):211-231. https://doi.org/ 10.1556/ceugeol.54.2011.3.1

Spezzaferri, S. and Ćorić, S. 2001. Ecology of Karpatian (Early Miocene) foraminifers and calcareous nannoplankton from Laa an der Thaya, Lower Austria: a statistical approach. Geologica Carpathica, 52(6):361-374.

Spezzaferri, S., Rögl, F., Ćorić, S., and Hohenegger, J. 2004. Paleoenvironmental reconstruction and agglutinated foraminifera from the Karpatian/Badenian (Early/Middle Miocene) transition in the Styrian Basin (Austria, Central Paratethys), p. 423-459. In Bubík, M. and Kaminski, M.A. (eds.), Proceedings of the 6th International Workshop on Agglutinated Foraminifera. Grzybowski Foundation Special Publication.

Spezzaferri, S., Ćorić, S., and Stingl, K. 2009. Palaeoenvironmental reconstruction of the Karpatian-Badenian (Late Burdigalian-Early Langhian) transition in the Central Paratethys. A case study from the Wagna Section (Austria). Acta Geologica Polonica, 59(4):523-544.

Stradner, H. 1959a. Die fossilen Discoasteriden Osterreichs. II. Erdoel-Zeitschrift, 75(12):472488.

Stradner, H. 1959b. First report on the discoasters of the Tertiary of Austria and their stratigraphic use. Proceedings of the Fifth World Petroleum Congress, 1:1081-1095.

Stradner, H. 1963. New contributions to Mesozoic stratigraphy by means of nannofossils. Proceedings of the Sixth World Petroleum Congress, Section 1, Paper 4:167-183.

Studencka, B. 1994. Middle Miocene bivalve faunas from the carbonate deposits of Poland (Central Paratethys). Géologie Méditerranéenne, 21(1-2):137-145. https://doi.org/10.3406/ geolm.1994.1503

Studencka, B., Gąsiewicz, A., and Czapowski, G. 2016. The Badenian-Sarmatian transition in the Central Paratethys: New data from the Carpathian Foredeep Basin in Poland seasonal record of the stable oxygen and carbon isotopes in the Late Badenian mollusks from the Central Paratethys (western Ukraine). 17th Czech-Slovak-Polish Palaeontological Conference, Abstract Volume, Krakow, p. 85.

Studencka, B. and Jasionowski, M. 2011. Bivalves from the Middle Miocene reefs of Poland and Ukraine: A new approach to Badenian/Sarmatian boundary in the Paratethys. Acta Geologica Polonica, 61(1):79-114.

Subbotina, N.N., Pishvanova, L.S., and Ivanova, L.V. 1960. Stratigraphy of Oligocene and Miocene sediments of the Ciscarpathians based on Foraminifera. Mikrofauna SSSR, Trudy Vsesoyuznogo Nauchno-Issledovatel'skogo Geologorazvedochnogo Instituta VNIGRI, 11(153):5-155. (In Russian)

Sukatcheva, I.D., Szalma, Š., Vršanský P., Chalupová, B., Golej, M., Labajová, E., and Smrečková, M. 2006. Caddis-fly (Insecta: Trichoptera) from the Badenian volcanosedimentary succession (Western Carpathians, Slovakia). Geologica Carpathica, 57(6):531534.

Talling, P.J., Sumner, E.J., Masson, D.G., Malgesini, G., 2012. Subaqueous sediment density flows: depositional processes and deposit types. Sedimentology, 185:202-233. https:// doi.org/10.1111/j.1365-3091.2012.01353.x

Tan, S.H. 1927. Discoasteridae incertae sedis. Proceedings of the Koninklijke Nederlandse Akademie van Wetenschappen, Section of Sciences, 30:411-419. 
Theodoridis, S. 1984. Calcareous nannofossil biostratigraphy of the Miocene and revision of the helicoliths and discoasters. Utrecht Micropaleontological Bulletin, 32:1-271.

Todd, R., Cloud, P.E., Low, D., and Schmidt, R.G. 1954. Probable occurrence of Oligocene on Saipan. American Journal of Science, 252:673-682.

Ustaszewski, K., Schmid, S.M., Fügenschuh, B., Tischler, M., Kissling, E., and Spakman, W. 2008. A map-view restoration of the Alpine-Carpathian-Dinaridic system for the Early Miocene. Swiss Journal of Geosciences, 101(Supplement 1):273-294. https://doi.org/ 10.1007/s00015-008-1288-7

Varol, O. 1989. Calcareous nannofossil study of the central and western Solomon Islands. Circum-Pacific Council for Energy and Mineral Resources Earth Sciences, 239-268.

Vekshina, V.N. 1959. Coccolithophoridae of the Maastrichtian deposits of the West Siberian lowlands. Siberian Science Research Institute of Geology Geophysics Mineralogy and Raw Materials, 2:56-81.

Vass, D. 1977. The Príbelce Formation, its sedimentary structures and origin. (Príbelské vrstvy, ich sedimentárne textúry a genéza). Západné Karpaty, Séria Geológia, 2:145-198. (In Slovak with English summary)

Vass, D. 1989. Alpine Molasse Basin as a mirror of genesis and development of block structures in the West Carpathians. Meeting of KGBA Comission on Stratigraphy, Paleogeography and Paleontology. Zeitschrift für Geologische Wissenschaften, 9(17):879-885.

Vass, D. 2002. Lithostratigraphy of Western Carpathians: Neogene and Buda Paleogene. Geologický Ústav Dionýza Štúra, Bratislava.

Vass, D., Konečný, V., and Šefara, J. (eds.) 1979. Geology of Ipel'ská kotlina (depression) and Krupinská planina Mts. (Geologická stavba Ipel'skej kotliny a Krupinskej planiny). Geologický Ústav Dionýza Štúra, Bratislava. (In Slovak with English summary)

Venables, W.N. and Ripley, B.D. 2002. Modern Applied Statistics with S, $4^{\text {th }}$ edition. Springer, New York.

von Fichtel, L. and von Moll, J.P.C. 1798. Testacea microscopica, aliaque minuta ex generibus Argonauta et Nautilus, ad naturam picta et descripta (Microscopische und andere klein Schalthiere aus den geschlechtern Argonaute und Schiffer). Camefinaifchen Buchhandlung, Vienna. https://doi.org/10.5962/bhl.title.10295

Wade, S.B. and Brown, R.P. 2006. Calcareous nannofossils in extreme environments: the Messinian Salinity Crisis, Polemi Basin, Cyprus. Palaeogeography, Palaeoclimatology, Palaeoecology, 233(3-4):271-286. https://doi.org/10.1016/j.palaeo.2005.10.007

Walker, G. and Jacob, E. 1798. Essays on the Microscope. Dillon and Keating, London.

Wallich, G.C. 1877. Observations on the coccosphere. Annals and Magazine of Natural History, 19:342-350.

Wells, P. and Okada, H. 1997. Response of nannoplankton to major changes in sea-surface temperature and movements of hydrological fronts over Site DSDP 594 (south Chatham Rise, southeastern New Zealand), during the last 130 kyr. Marine Micropaleontology, 32(34):341-363. https://doi.org/10.1016/s0377-8398(97)00025-x

Wiedl, T., Harzhauser, M., Kroh, A., Ćorić, S., and Piller, W.E. 2013. Ecospace variability along a carbonate platform at the northern boundary of the Miocene reef belt (Upper Langhian, Austria). Palaeogeography, Palaeoclimatology, Palaeoecology, 370:232-246. https://doi.org/ 10.1016/j.palaeo.2012.12.015

Williamson, W.C. 1848. On the Recent British species of the genus Lagena. Annals and Magazine of Natural History, 2(1/1):1-20.

Williamson, W.C. 1858. On the Recent Foraminifera of Great Britain. The Ray Society, London. https://doi.org/10.5962/bhl.title.139719

Wise, S.W. 1973. Calcareous nannofossils from cores recovered during Leg 18, Deep Sea Drilling Project: biostratigraphy and observations on diagenesis. Initial Reports of the Deep Sea Drilling Project, 18:569-615.

Young, J.R. 2003. How many species? Analysis of extant nannoplankton biodiversity. Gaia, 11:87-87.

Young, J.R. and Bown, P.R. 2014. Some emendments to calcareous nannoplankton taxonomy. Journal of Nannoplankton Research, 33(1):39-46.

Young, J.R., Bown, P.R., and Lees, J.A. 2017. Nannotax3 website. International Nannoplankton Association. Accessed 21 April 2017. http://www.mikrotax.org/Nannotax3 
Winter, A., Jordan, R.W., and Roth, P.H. 1994. Biogeography of living coccolithophores in ocean waters, 161-177. In Winter, A. and Siesser, W. (eds.), Coccolithophores. Cambridge University Press, Cambridge.

Zachos, J., Pagani, M., Sloan, L., Thomas, E., and Billups, K. 2001. Trends, rhythms, and aberrations in global climate $65 \mathrm{Ma}$ to present. Science, 292(5517):686-693. https://doi.org/ $10.1126 /$ science. 1059412

Zlinská, A. and Šutovská, K. 1991. Biostratigraphy of the Príbelce Member. Mineralia Slovaca, 23(3):245-250. (In Slovak with English abstract)

Zuschin, M., Harzhauser, M., and Mandic, O. 2004. Spatial variability within a single parautochthonous Paratethyan tidal flat deposit (Karpatian, Lower Miocene - Kleinebersdorf, Lower Austria). Courier Forschungsinstitut Senckenberg, 246:153-168. 


\section{APPENDICES}

All appendices are included in a zipped file for download at https://palaeo-electronica.org/content/2020/3198-south-slovakia-neogene-basins.

\section{APPENDIX 1.}

Description and interpretation of lithofacies in the studied sections.

\section{APPENDIX 2.}

List of nannoplankton from non-barren samples.

\section{APPENDIX 3.}

List of foraminifera. A. Planktic foraminifera from non-barren samples. B. Benthic foraminifera from non-barren samples. C. Depth ranges of foraminifera.

\section{APPENDIX 4.}

Polpal outcome chart - list of palynomorphs. 